\title{
Tidal Influence on Nutrients Status and Phytoplankton Population of Okpoka Creek, Upper Bonny Estuary, Nigeria
}

\author{
O. A. Davies ${ }^{1}$ and O. A. Ugwumba ${ }^{2}$ \\ ${ }^{1}$ Department of Fisheries and Aquatic Environment, Rivers State University of Science and Technology, \\ P. M. B. 5080, Port Harcourt, Nigeria \\ ${ }^{2}$ Hydrobiology and Fisheries Unit, Department of Zoology, University of Ibadan, Ibadan 900001, Nigeria \\ Correspondence should be addressed to O. A. Davies; daviesonome@yahoo.com
}

Received 26 April 2013; Revised 24 July 2013; Accepted 25 July 2013

Academic Editor: E. A. Pakhomov

Copyright (c) 2013 O. A. Davies and O. A. Ugwumba. This is an open access article distributed under the Creative Commons Attribution License, which permits unrestricted use, distribution, and reproduction in any medium, provided the original work is properly cited.

Okpoka Creek of the Upper Bonny Estuary in the Niger Delta is a tidal creek receiving organic anthropogenic effluents from its environs. The study investigated the influence of tides (low and high) on the species composition, diversity, abundance, and distribution of phytoplankton. The surface water and phytoplankton samples were collected monthly from May 2004 to April 2006 at both tides from ten stations according to standard methods. Phytoplankton was identified microscopically. Species diversity was calculated using standard indices. Data analyses were done using analysis of variance, Duncan multiple range, and descriptive statistics. Phosphate and ammonia exceeded international acceptable levels of $0.10 \mathrm{mg} / \mathrm{L}$ for natural water bodies indicating high nutrient status, organic matter, and potential pollutants. A total of 158 species of phytoplankton were identified. Diatoms dominated the phytoplankton (62.9\%). Diversity indices of diatoms were $1.5 \pm 0.03$ (Margalef) and $0.8 \pm 0.01$ (Shannon). Pollution-indicator species such as Navicula microcephala, Nitzschia sigma, Synedra ulna (diatoms), Cladophora glomerata (green alga), Euglena acus (euglenoid), Anabeana spiroides (blue-green alga), and Ceratium furca (dinoflagellate) were recorded at either only low, high or both tides. Concerted environmental surveillance on Upper Bonny Estuary is advocated to reduce the inflow of pollutants from the Bonny Estuary into this Creek caused by tidal influence.

\section{Introduction}

Estuaries are unique aquatic environments that have an additional source of buoyancy input derived from riverine freshwater inflow and an additional source of mechanical energy input from the tides (tidal stirring). Estuarine ecosystems are very favourable for algae and animal life. They play an important ecological role because they are natural habitants of water. They are widely used as an indicator of water pollution [1]. The Bonny Estuary is one of the several estuaries in the Niger Delta swamps through which the Lower Niger and Benue Rivers flow into the ocean. The estuary is richly endowed with abundant aquatic resources (creeks, distributaries, flood plains and mangrove swamps with fin/shell fish resources, etc.). The estuary, its creeks, and tributaries consist of rich collection of flora and fauna constituting a unique tropical biodiversity. The vegetation of
Bonny Estuary is dominated by the red mangrove Rhizophora racemosa and $R$. mangle [2]. The mangrove provides nurseries and feeding grounds for commercially important species of finfish and shellfish. Despite its good environment for aquatic life forms, the area is prone to pollution resulting from industries located along the shore of Bonny Estuary which are concentrated in this zone and they discharge their effluents directly into the estuary. The flushing action of the tidal flows contributes to moving these pollutants down into the coastal zones. Okpoka Creek is a tidal tributary of the Upper Bonny Estuary. Tidal influence on this creek is twenty-four hours at interval of six hours of low and high tides alternatively.

Tides play a major role in the functioning of many coastal systems. They are responsible for obvious midterm (spring-neap cycles) and short-term (low-high water cycles) variations in the abiotic and biotic characteristics of these 
systems [3]. Tidal flushing is one of the main bottom-up factors controlling phytoplankton biomass in estuaries besides nutrients [4]. Quite a number of works had been conducted to evaluate tidal control of plants and animals communities and processes in different systems. These include tide-induced phytoplankton and microphytobenthos exchanges [5]; tidal influence on bacteria, microphytoplankton, and microzooplankton abundance [6]; tidal stirring and phytoplankton bloom dynamic in an estuary [7]; tidal influence on zonation and occurrence of resident and temporary zooplankton in Mundaka Estuary, Bay of Biscay [3]; and effects of tidal shallowing and deepening on phytoplankton production dynamics: a modeling study [8] and dancing with the tides: fluctuations of coastal phytoplankton orchestrated by different oscillatory modes of the tidal cycle [9].

Phytoplankton populations are highly dynamic, and in many environments they experience episodes of rapid biomass increase (blooms), either as recurrent seasonal events or as higher frequency phenomena [7]. According to Badsi [1], Rajesh et al. [10], Ananthan et al. [11], Tiwari and Chauhan [12], Tas and Gonulol [13] and Saravanakumar et al. [14], phytoplanktonic organism is one of the initial biological components from which the energy is transferred to higher organisms through food chain. The density and the diversity of phytoplankton are biological indicators for evaluating water quality and the degree of eutrophication $[1,15,16]$.

There are many human activities going on around and in the creek such as slaughtering of animal, transportation (boating, navigation), fishing, and waste disposal. However, there has been no information on the influence of tide on the nutrients status and phytoplankton community of Okpoka Creek, a tidal tributary of Upper Bonny Estuary. In order to bridge the existing gap in knowledge of the biotic and abiotic features of this estuary, there is therefore the need to provide useful information on the tidal variations of water nutrients and phytoplankton population of this Creek. Based on this, the study thus evaluated the influence of low and high tides on nutrients, abundance, species composition, diversity, and distribution of the phytoplankton of Okpoka Creek.

\section{Materials and Methods}

2.1. Study Area. Okpoka Creek is located between longitudes $7^{\circ} 00^{\prime \prime} \mathrm{E}$ and $7^{\circ} 15^{\prime \prime} \mathrm{N}$ and latitudes $4^{\circ} 28^{\prime \prime} \mathrm{E}$ and $4^{\circ} 40^{\prime \prime} \mathrm{N}$ (Figure 1). The vegetation is dominated by nypa palm (Nypa frutican) and mangroves, red mangrove (Rhizophora racemosa), and white mangrove (Avicennia nitida). It passes through many communities, namely, Oginigba, Woji, and Azubiae. Many man's activities going on within and around this creek include dredging, fishing, boating, navigation, washing, disposal of excreta, bathing, and swimming, to mention but a few. This aquatic body receives effluent discharges from the many industries (Snig, Far East paints, RIVOC, General-agro, Michelin tyres, Coca Cola, Halliburton, Schlumberger, Acorn, etc.) and main abattoir house sited close to it. The stretch of the coastal front of the creek has very high population density without waste management facilities.
All the industries in the Trans-Amadi Industrial Layout and the riverine dwellers discharge their wastes directly to this creek.

2.2. Sampling Stations. A total of ten stations were chosen at least 500 metres apart along the main creek course. These stations were Station 1 (Oginigba), Station 2 (Trans-Amadi by Schlumberger), Station 3 (by main abattoir house), Station 4 (Azubiae), Station 5 (Woji), Station 6 (Okujagu), Station 7 (Okuru-ama), Station 8 (Ojimba), Station 9 (Oba-ama), and Station 10 (Kalio-ama). There are many industries sited close to the river shore discharging effluents into the creek. The dominant vegetation is nypa palm (Nypa frutican) followed by drying up red mangrove. Patches of water hyacinth were seen during the rainy season. Manual dredging of sand is constantly going on.

2.3. Physicochemical Parameters of the Water. The following parameters were measured in situ and in laboratory following standard methods [17]. One-litre clean containers were used to collect water samples for physicochemical parameters at each station. All the kegs containers were kept in icechest box for laboratory analyses. Nitrate was determined by the Brucine method [17]. Spectrophotometer (spectronic 21D) was used to measure the nitrate at $410 \mathrm{~nm}$ wavelength. Sulphate determination was carried out by turbidimetric procedure [17]. This involved the use of spectrophotometer (Spectronic 21D). The concentration of sulphate $(\mathrm{mg} / \mathrm{L})$ was measured; thus,

$$
\text { Sulphate }=\frac{\mathrm{mgSO}_{4} \times 1000}{\text { Volume of sample used }(\mathrm{mL})} .
$$

Phosphate-in-water levels were determined by standard test [17]. It involved the use of spectrophotometer (Spectronic 21D). The concentration of phosphate $(\mathrm{mg} / \mathrm{L})$ was measured; thus,

$$
\text { Phosphate }=\frac{\mathrm{mgPO}_{4} \times 1000}{\text { Volume of sample used }(\mathrm{mL})}
$$

Ammonia concentrations in water samples were determined by the indophenol or phenate (phenol-hypochlorite) method. It was spectrophotometrically measured at $630 \mathrm{~nm}$ wavelength with spectronic 21D [17]. The concentration of total ammonia in the samples was computed from the equation

$$
\frac{C_{1}}{C_{2}}=\frac{A_{1}}{A_{2}}
$$

where $A_{1}=$ the absorbance of the total ammonia-nitrogen standard, $A_{2}=$ the absorbance of the sample, and $C_{1}=$ the concentration of the total ammonia-nitrogen standard. $C_{2}=$ the concentration of total ammonia nitrogen in the sample (Boyd [18]). 


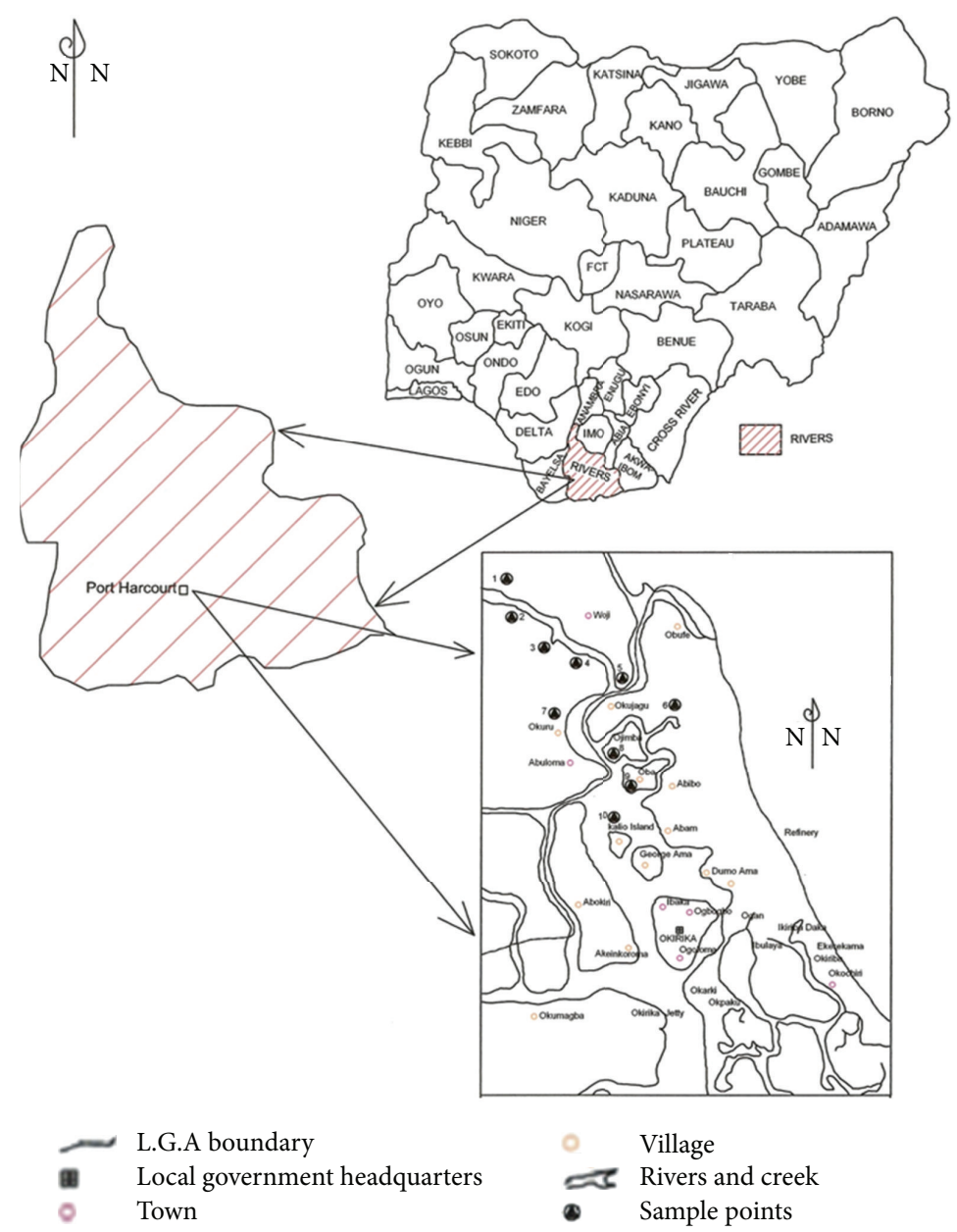

FIGURE 1: Study area map.

2.4. Collection of Phytoplankton Samples and Analyses. Samplings were done at low and high tides. Surface water samples were collected using one, one-litre wide mouth, plastic container [17] at each station. The sample in the container was fixed with $10 \%$ formalin for phytoplankton identification and enumeration (standing crop estimation). In the laboratory, samples were allowed to stand for a minimum of 24 hours before decanting the supernatant. The supernatant was removed carefully until a $50 \mathrm{~mL}$ concentrated sample was properly shaken, and $1 \mathrm{~mL}$ of sub sample was collected from it and transferred into a Sedgwick-Rafter counting chamber using a stampel pipette. Identification and enumeration (standing crop estimation) was carried out under a binocular compound microscope with magnification $40 \times 400$. Three replicates of the subsamples were analysed. For each sample, each solitary cell or group of cells were counted as one unit except for the diatoms which were counted in a cell by cell base. Results were expressed in a number of organisms per $\mathrm{mL}$ of sample. The Sedgwick-Rafter counting chamber contains exactly $1 \mathrm{~mL}(50 \mathrm{~mm}$ long $\times 20 \mathrm{~mm}$ wide $\times 1 \mathrm{~mm}$ deep) and has a surface area of $1000 \mathrm{~mm}^{2}$. The exact area viewed within the ocular micrometer grid is also known.
The following formula was used for the calculation of plankton density:

Density of plankton (Number of plankters per mL)

$$
=(T) \frac{1000}{\mathrm{AN}} \times \frac{\text { Volume of concentrate } \mathrm{mL}}{\text { Volume of sample }(\mathrm{mL})},
$$

where $T=$ total number of plankters counted, $A=$ area of grid in $\mathrm{mm}^{2}, N=$ number of grids employed, and 1,000 = area of counting chamber in $\mathrm{mm}^{2}$ (Boyd [18]).

Identification and characteristics of planktonic species were made by the descriptive keys by J. G. Needham and P. R. Needham [19]; G. E. Newell and R. C. Newell [20]; Patrick and Reimer [21], Han [22], Durans and Leveque [23], and Prescott [24]; and Kadiri [25] amongst others. Margalef species diversity index was estimated by this formula

$$
H=\frac{S-1}{\operatorname{In} N}
$$

where $S=$ the number of species (or other taxonomic group) and $N=$ total number of phytoplankters (Boyd [18]). 
TABLE 1: Important values assigned to $i$ th species abundance.

\begin{tabular}{lc}
\hline Range & Importance value \\
\hline $1-10$ & 1 \\
$11-20$ & 2 \\
$21-30$ & 3 \\
$31-40$ & 4 \\
$41-50$ & 5 \\
$51-60$ & 6 \\
$61-70$ & 7 \\
$71-80$ & 8 \\
$81-90$ & 9 \\
$91-100$ & 10 \\
100 and above & 11 \\
\hline
\end{tabular}

Index of dominance $(C)$ was determined by the formula

$$
C=\sum\left(\frac{n i}{N}\right)^{2}
$$

where $n i=$ importance value for each species (number of individual, biomass, production, etc.) and $N=$ total of importance values.

Importance values (Table 1) were assigned to the phytoplankton species based on the contribution of each species to total net primary production [26] and also to pollution.

Index of similarity $(S)$ in phytoplankton species diversity between the low and high tides was determined by index of similarity $(S)$ between 2 adjacent samples [26] as follows:

$$
S=\frac{2 C}{A+B},
$$

where $A=$ number of species in sample $A, B=$ number of species in sample $B$ and $C=$ number of species common in both samples

$$
\text { Index of dissimilarity }=I-S \text {. }
$$

Other indices of species diversity calculated are as follows.

(1) Shannon index of general diversity $(H)$ was calculated thus

$$
H=\sum\left(\frac{n i}{N}\right) \log \left(\frac{n i}{N}\right) \quad \text { or } \quad-\sum P i \log P i,
$$

where $n i=$ importance value for each species, $N=$ total of importance values, and $P i=$ importance probability for each species $=n i / N$.

(2) Evenness index $(e)$ is

$$
e=\frac{H}{\log _{e} S}
$$

where $H=$ Shannon index and $S=$ number of species.

\section{Data Analyses}

SAS [27] was used to analyse data for analysis of variance (ANOVA), Duncan multiple range (DMR) and descriptive statistics.
TABLE 2: Variations of water nutrients in relation to tide in Okpoka Creek.

\begin{tabular}{ccccc}
\hline Tide & $\begin{array}{c}\text { Ammonia } \\
(\mathrm{mg} / \mathrm{L})\end{array}$ & $\begin{array}{c}\text { Nitrate } \\
(\mathrm{mg} / \mathrm{L})\end{array}$ & $\begin{array}{c}\text { Phosphate } \\
(\mathrm{mg} / \mathrm{L})\end{array}$ & Sulphate $(\mathrm{mg} / \mathrm{L})$ \\
\hline Low & $0.17 \pm 0.01^{\mathrm{a}}$ & $0.68 \pm 0.02^{\mathrm{a}}$ & $0.77 \pm 0.05^{\mathrm{a}}$ & $586.11 \pm 36.42^{\mathrm{a}}$ \\
High & $0.19 \pm 0.02^{\mathrm{a}}$ & $0.48 \pm 0.04^{\mathrm{b}}$ & $0.29 \pm 0.07^{\mathrm{b}}$ & $459.09 \pm 33.89^{\mathrm{a}}$ \\
\hline
\end{tabular}

Means with the same letter in the same column are not significantly different $(P>0.05)$.

\section{Results and Discussion}

4.1. Nutrients of Surface Water from Okpoka Creek. Generally, phytoplankton growth is limited by inorganic nutrients (phosphorous, nitrogen, silicon, iron, etc.). Nutrients status affects the composition of phytoplankton as its composition changes with the nutrient fluxes because individual taxa have different requirements. High tide ammonia level $(0.19 \pm 0.02 \mathrm{mg} / \mathrm{L})$ was not significantly $(P>0.05, \mathrm{DMR})$ higher than low tide ammonia $(0.17 \pm 0.01 \mathrm{mg} / \mathrm{L})$ with a mean of $0.17 \pm 0.01 \mathrm{mg} / \mathrm{L}$ (Table 2). This possibly indicated anthropogenic inputs from the numerous industries and riverine dwellers located along the water course of Okpoka Creek at high tide. Higher concentration of ammonia at high tide favoured the observed diatoms, green algae, bluegreen algae, dinoflagellates, and xanthophytes especially the dominant diatoms at high tide. The lower concentration of ammonia at low tide favoured the other phytoplankton groups (chrysophytes and euglenoids). Ammonia is one of the nutrients required by phytoplankton for primary productivity. Others are nitrate, phosphorus, and sulphate [28]. Furthermore, ammonia is a source of nitrogen and contributes to the fertility of water since nitrogen is an essential plant nutrient. It is also one of the most important pollutants in aquatic environment because of its relative high toxic nature and its ubiquity in surface water systems [29]. Ammonia enters natural water systems from several sources including industrial wastes, sewage effluents, coal gasification and liquefaction conversion process plants, and agricultural discharge including feedlot runoff. The study ammonia exceeded the concentration of less than $0.1 \mathrm{mg} / \mathrm{L}$ found in natural waters [30]. This possibly indicates anthropogenic and domestic inputs. The mean ammonia concentration is also higher than the level of $0.02 \mathrm{mg} / \mathrm{L}$ unionized ammonia $\left(\mathrm{NH}_{3}\right)$ required for the protection of aquatic life [31]. However, the recorded range of ammonia in this creek is within the range of $0.093 \mathrm{mg} / \mathrm{L}$ to $2.65 \mathrm{mg} / \mathrm{L}$ reported by Chindah and Nduaguibe [32] and Obunwo et al. [33] in the Niger Delta.

Nitrate nitrogen and ammonia nitrogen determine community productive levels. The lower concentrations of sulphate, nitrate, and phosphate at high tide might signified low primary productivity. Tides cause a pattern of stabilizationdestabilization in circulation that results in the highest rates of primary production in many estuarine, coastal, oceanic, or frontal environments [34]. Destabilization period occurs during flood or ebb tides or during fast current movement. This results in a replenishment of nutrients to the photic zone from more nutrient-rich underlying waters. During 
and following the destabilization period, photosynthesis is decreased by a shortage of light due to increased turbidity and mixing of the phytoplankton to deeper waters. Circulation patterns are vital in establishing the balance between light levels and nutrient availability necessary to maintain high primary productivity rates in marine systems.

The higher concentration of nitrate, phosphate, and sulphate at low tide might be attributed to the higher abundance of chrysophytes and euglenoids at low tide. These nutrients indicated high primary productivity and that these phytoplankters are primary producers. At low tide, stabilization in circulation leads to increased rate of photosynthesis. Stabilization period occurs during slack tides or slow currents and results in increased rates of photosynthesis and nutrient uptake [34]. Nutrients availability especially phosphorus structures the algae community [35]. In addition, primary productivity (phytoplankton productivity) is expected to be high at low tide (low water) as turbidity is low and solar and light penetrations are high.

Nitrate concentration $(0.68 \pm 0.02 \mathrm{mg} / \mathrm{L})$ was high at low tide and low $(0.48 \pm 0.04 \mathrm{mg} / \mathrm{L})$ at high tide with a mean of $0.64 \pm 0.02 \mathrm{mg} / \mathrm{L}$. The highest nitrate recorded at low tide might be indicative of high human excrement and industrial discharges. Stabilization period occurs during slack tides or slow currents and results in increased rates of nutrient uptake [34]. This also might be the possible reason for this observation. Tidal effect was highly significant $(P<$ $0.001, \mathrm{DMR})$. The observed mean nitrate is below $100 \mathrm{mg} / \mathrm{L}$ expected to be found in natural surface water. Nitrogen is most often limiting in marine systems [36]. The reasons being that molybdenum, phosphorus, or energy constraint can be limiting to nitrogen fixers, which makes for lower nitrogen fixation [37]. The range of nitrate recorded in this study was below the statutory limit of $25-50 \mathrm{mg} / \mathrm{L}$ given by the European Economic Community (EEC) [38] and $20 \mathrm{mg} / \mathrm{L}$ United State Environment Protection Agency (USEPA) [39]. Low tide phosphate level $(0.77 \pm 0.05 \mathrm{mg} / \mathrm{L})$ was higher than that of high tide $(0.29 \pm 0.07 \mathrm{mg} / \mathrm{L})$ with a mean of $0.70 \pm$ $0.05 \mathrm{mg} / \mathrm{L}$. The effect of tide was significant $(P<0.05$, DMR).

The higher phosphate at low tide could be due to high decomposition of organic matter and stabilization period. Tide influence on the sulphate concentrations was not significant $(P>0.05)$. The recorded phosphate concentrations in this study were higher than the acceptable limit of $0.10 \mathrm{mg} / \mathrm{L}$ in flowing waters recommended by USEPA [39] and United States Geological Survey (USGS) [40]. This observation agrees with that of 0.43 to $3.52 \mathrm{mg} / \mathrm{L}$ of Chindah and Nduaguibe [32].

Low tide mean sulphate level was $586.11 \pm 36.42 \mathrm{mg} / \mathrm{L}$ (higher) and high tide level was $459.09 \pm 33.89 \mathrm{mg} / \mathrm{L}$ (lower) with a mean value of $560.05 \pm 28.87 \mathrm{mg} / \mathrm{L}$. This could be attributed to the higher biological oxygen demand and stabilization period at low tide than at high tide. Oxidation of the organic materials and burning of fossil fuel used up oxygen, thereby exerting higher biological oxygen demand in the creek. The high sulphate level observed in this study is characteristic of brackish water. Ebere [41] reported that marine waters are known to contain relatively high concentrations of sulphate. McNeely et al. [30] observed $2650 \mathrm{mg} / \mathrm{L}$

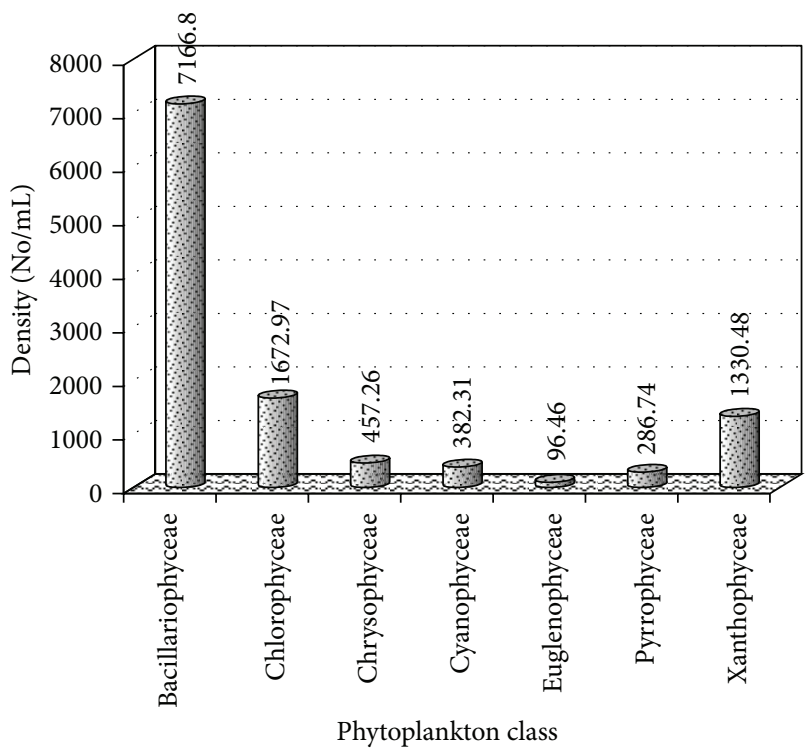

FIGURE 2: Overall mean value of phytoplankton density in Okpoka Creek.

sulphate in seawater. The recorded sulphate is below the sulphate values in seawater, that is, within the acceptable levels.

4.2. Phytoplankton Community of Okpoka Creek. Phytoplankton are free-floating, and mostly microscopic plants, and they cannot swim; instead, they are transported by tides and currents. A total of forty-nine thousand four hundred and seventy nine $(48,479)$ phytoplankton consisting of seven $(7)$ families, seventy-nine (79 genera), and one hundred and fifty-eight (158) species were identified. These values were more than the values reported for studies on other waters of the Niger Delta. This could be due to environmental influence. The algae were Bacillariophyceae (diatoms), 80 species; Chlorophyceae (green algae), 44 species; Cyanophyceae (blue-green algae), 21 species; Euglenophyceae (euglenin), 6 species; Pyrrophyceae (dinoflagellates), 4 species; Xanthophyceae (xanthophytes), 2 species; and Chrysophyceae (chrysophytes), 1 species. The observed abundance of phytoplankton differs with that of Edoghotu [42] for Okpoka Creek though it agrees with that study in terms of diatoms being the most abundant phytoplankton. Other studies in the Niger Delta of Nigeria are those of Chindah, and Keremah [43], Chindah and Braide [44, 45] on the Bonny Estuary. Diatom dominance in this creek corresponded with the study of Badsi et al. [1] on Massa Estuary. Diatoms recorded the highest density (Figure 2) and this indicated high productivity of Okpoka Creek according with Badsi et al. [1]. Also, Moser et al. [46] stated that diatoms are sensitive to a wide range of limnological and environmental variables, and that their community structure may quickly respond to changing physical, chemical, and biological conditions in the environment. This might be the possible reason for the dominance of diatoms in Okpoka Creek. In addition, reasons for the varied tidal abundance, distribution, species 


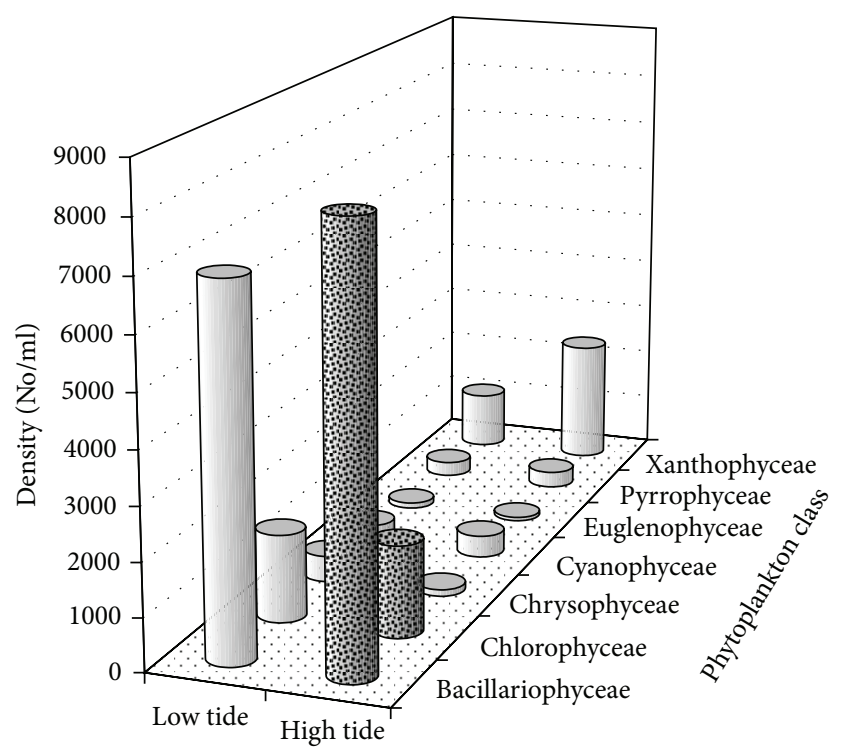

$\begin{array}{ll}\text { 图 Bacillariophyceae } & \square \text { Euglenophyceae } \\ \square \text { Chlorophyceae } & \square \text { Pyrrophyceae } \\ \square \text { Chrysophyceae } & \square \text { Xanthophyceae } \\ \square \text { Cyanophyceae } & \end{array}$

FIGURE 3: Variation of phytoplankton density. Variations of phytoplankton parameters in relation to tide in Okpoka Creek.

composition, and diversity of diatoms could be ascribed to their resilient ability to withstand organic pollution. Furthermore, dominance of diatoms in terms of abundance and species composition indicates pollution [47]. This shows that diatoms are resilient to the increased anthropogenic inputs and high turbidity at high tide. The recorded abundance of the other phytoplankton classes explains this resilient ability of diatoms. Nevertheless, some algae inhibit the growth of others, for example, Pyrmnesium parvum suppresses other algae by production of allelopathic chemical [48]. Passy et al. [49] reported that diatoms distribution is associated with a downstream increase in nutrient level and organic pollution.

Chrysophytes and euglenoid flagellates recorded higher density at low tide $(495.31 \pm 79.33 \mathrm{no} / \mathrm{mL}$ and $105.74 \pm$ $19.55 \mathrm{no} / \mathrm{mL})$ than at high tide $(124.25 \pm 33.99 \mathrm{no} / \mathrm{mL}$ and $68.63 \pm 17.78 \mathrm{no} / \mathrm{mL}$ ) (Figure 3 ). This could possibly be explained by the stabilization in circulation. The stabilization in circulation favoured these algae. The other observed algae recorded higher densities at high tide than at low tide. Tidal cycle is a major determinant of phytoplankton fluctuations at several different time scales [9]. A pattern of stabilizationdestabilization in circulation results in the highest rates of primary production in many estuarine, coastal, oceanic, or frontal environments [34]. Stabilization period occurs during slack tides or slow currents and results in increased rates of photosynthesis and nutrient uptake. On the other hand, destabilization period is experienced during flood or ebb tides or during fast current movement results in a replenishment of nutrients to the photic zone from more nutrient-rich underlying waters. During and following the destabilization period, photosynthesis is decreased by a shortage of light due

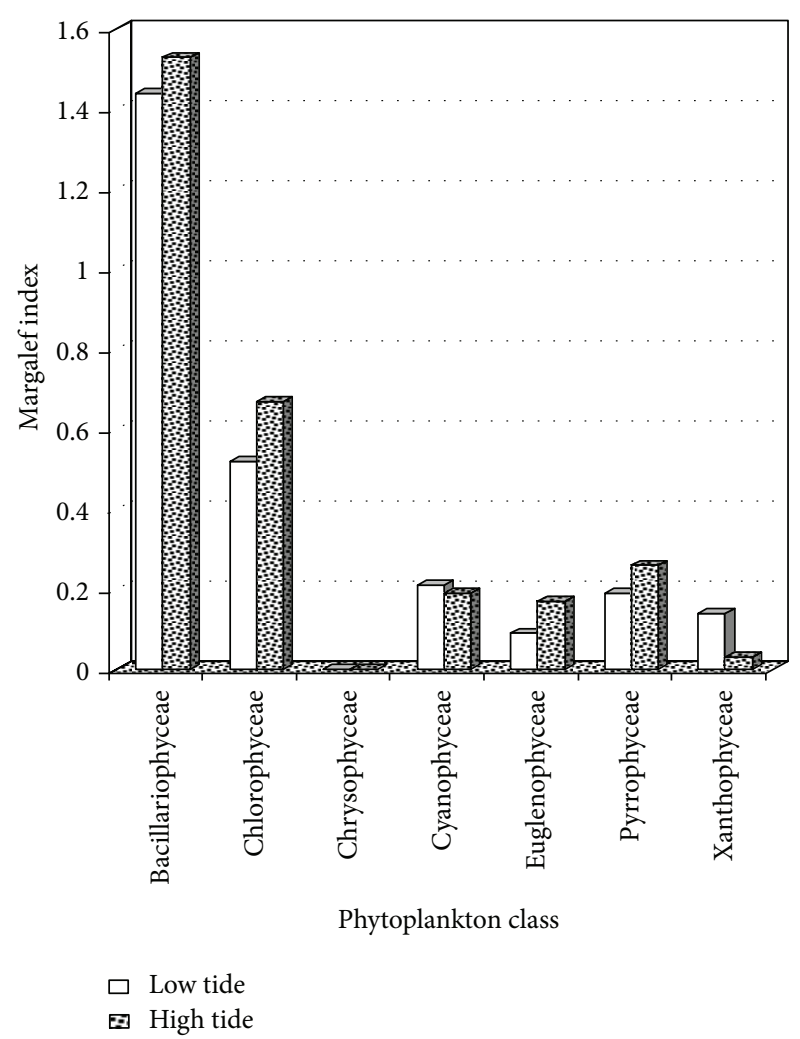

Figure 4: Variation of phytoplankton Margalef index. Variations of phytoplankton parameters in relation to tide in Okpoka Creek.

to increased turbidity and mixing of the phytoplankton to deeper waters [34]. Therefore, circulation patterns are vital in establishing the balance between light levels and nutrient availability necessary to maintain high primary productivity rates in marine systems. The higher phytoplankton biomass at low tide than at high tide was also reported by Okpuruka [50] of Elechi Creek in the Niger Delta. Okpuruka [50] reported that Elechi Creek of the Upper Bonny Estuary in the Niger Delta had higher phytoplankton diversity during spring tides than neap tides.

4.3. Bacillariophyceae (Diatoms). Diatoms density ranged from $6908.92 \pm 394.37 \mathrm{no} / \mathrm{mL}$ (low tide) to $8140.29 \pm$ $729.63 \mathrm{no} / \mathrm{mL}$ (high tide) with a mean value of $7166.80 \pm$ $347.73 \mathrm{no} / \mathrm{mL}$ which was $62.91 \%$ total abundance of phytoplankton (Figures 2 and 3). High tide phytoplankton parameters [density $(8140.29 \pm 729.63 \mathrm{no} / \mathrm{mL})$, Margalef $(1.53 \pm 0.05)$, Shannon $(0.84 \pm 0.02)$, Evenness $(0.42 \pm 0.01)]$ were higher except Dominance $(0.15 \pm 0.01)$ than at low tide [density $(6908.92 \pm 394.37 \mathrm{no} / \mathrm{mL})$ Margalef $(1.44 \pm$ $0.03)$, Shannon $(0.77 \pm 0.01)$, and Evenness $(0.40 \pm 0.01)$, and Dominance $(0.18 \pm 0.01)$ ] (Figures 2, 4, 5, 6, and 7). Tidal effects were significant on all phytoplankton parameters except Margalef and Dominance indices $(P<0.01, \mathrm{DMR})$.

The presence of diatoms at both tides indicated that species are euryhaline. High values of these parameters except Dominance index signified high diversity of diatoms at high tide. This observation could be attributed to tidal 


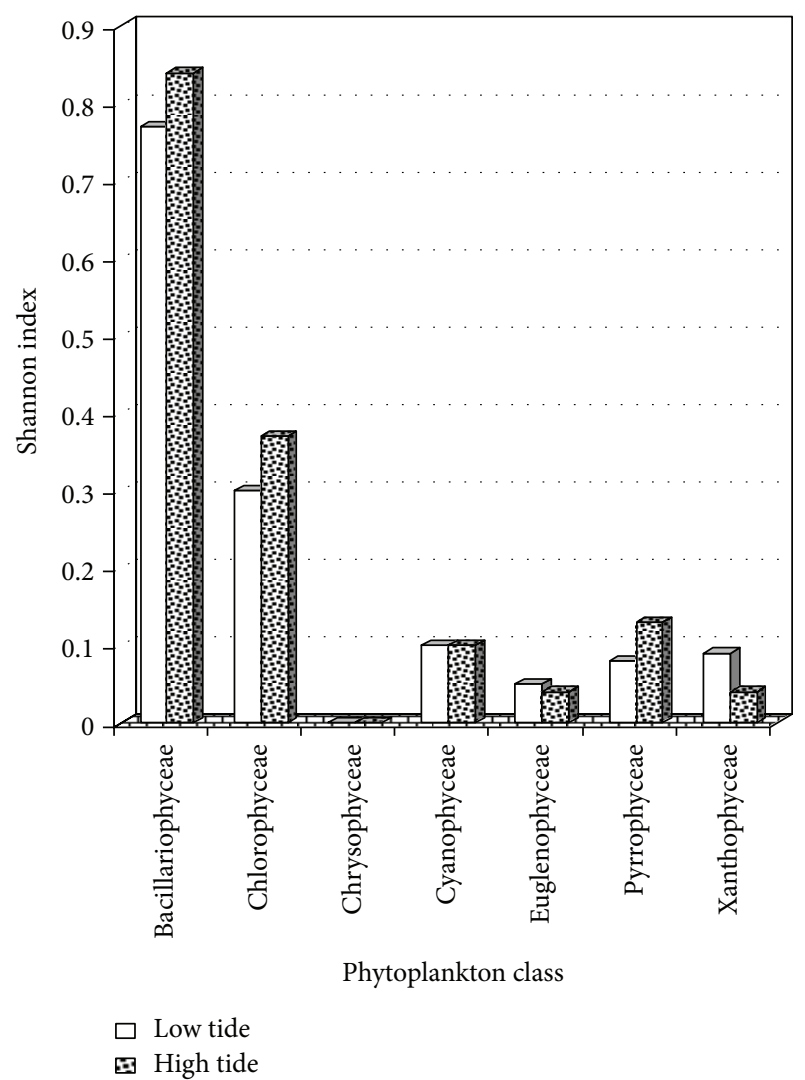

FIGURE 5: Variation of phytoplankton Shannon index. Variations of phytoplankton parameters in relation to tide in Okpoka Creek.

influence. At high tide, there is inflow of water from the sea into Okpoka Creek via the Upper Bonny Estuary that brings in phytoplanktonic organisms and other aquatic life. Phytoplankton are passively drifted microscopic plants, thus, some marine diatom species might moved into this creek. Tidal flushing is one of the main bottom-up factors controlling phytoplankton biomass in estuaries besides nutrients [4]. According to Villate [3], tides are responsible for obvious midterm (spring-neap cycles) and short-term (low-high water cycles) variations in the abiotic and biotic characteristics of estuaries. The recorded higher dominance index at low tide might indicate that the observed diatom species were true species (permanent residents) of this creek. The Shannon index value below 3 up to 3 at both tides showed a low specific structure of this group. Based on principle, a low diversity is a feature of young settlements of species; while a high diversity indicates mature settlements, the low diversity index shows a weak internal structure of populations [1]. The lower abundance and species diversity of diatoms at low tide could be linked with the cycle of advection, settling, and resuspension that follow the suspended particles during the ebb, slack, and flood tidal stages. This cycle facilitates the retention of passive diatoms by physical trapping in the Okpoka Creek. In this creek, the pattern of abundance and species diversity of diatoms match the tidal cycles suggesting that diatoms are displaced along the creek within a determinate mass of water. This means that physical trapping

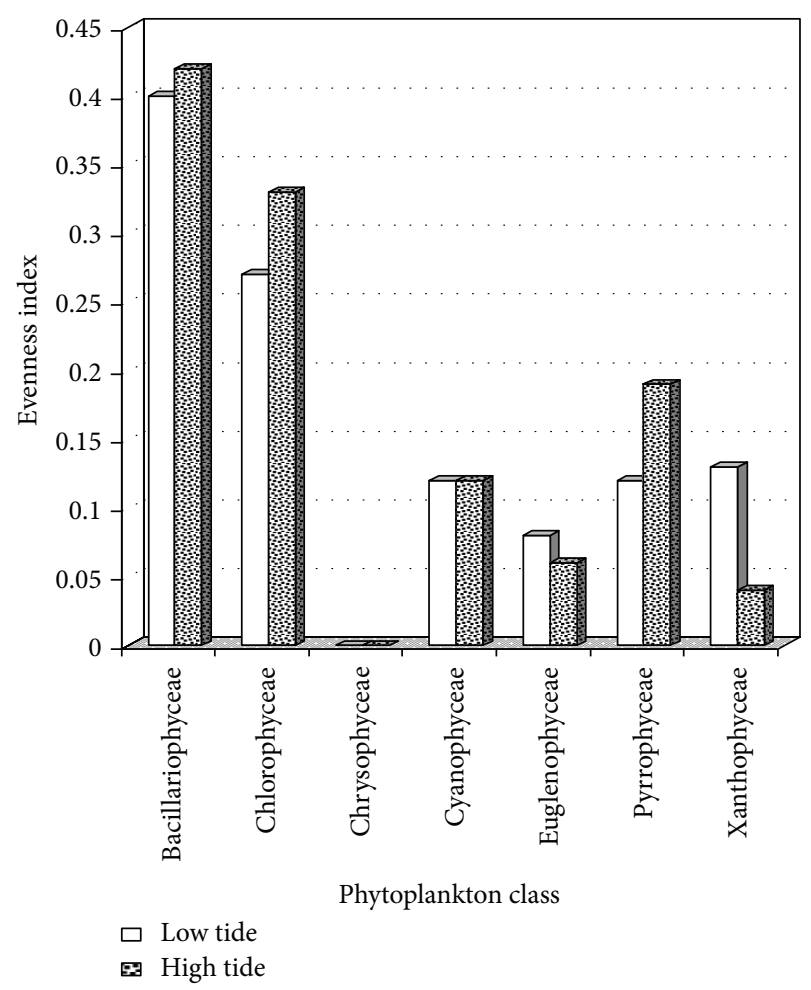

FIGURE 6: Variation of phytoplankton evenness index. Variations of phytoplankton parameters in relation to tide in Okpoka Creek.

and high water residence times serve to trap passively sinking particles, such as diatoms, without migrating behaviours in their optimum estuarine environments [4].

There were 4 dominant genera and 10 prominent diatoms species out of the 80 observed species (Table 3 ). The species were Melosira undulata $(26.03 \pm 16.05 \%)$, Cyclotella operculata $(17.24 \pm 1.63 \%)$, M. pusilla (17.66 $\pm 0.96 \%)$, Nitzschia sigma $(15.15 \pm 1.64 \%), M$. distans $(12.16 \pm 4.13 \%), N$. bilobata $(11.39 \pm 1.95 \%)$, M. varians $(12.54 \pm 0.73 \%)$, Navicula bacillum $(11.37 \pm 1.18 \%)$, Cyclotella comta $(10.89 \pm 1.32 \%)$, and Nitzschia filiforms $(11.32 \pm 0.85 \%)$. Tide had varied significant effects on these 10 dominant species $(P<0.05$, DMR). Percentage abundances of C. comta, Nitzschia bilobata, N. sigma, and Navicula bacillum were significantly higher at low tide than at high tide except $N$. sigma $(P<0.05)$ while the opposite was observed for C. operculata, M. varians, and $M$. distans. Percentage abundances of $C$. operculata and $M$. distans were not significantly different $(P>0.05)$. N. filiforms, M. undulate, and M. pusilla were absent at low tide. Navicula gracilis, N. cuspidata, N. placentula, N. microcephala, N. bacillum, N. amphibola, Nitzschia sigma, N. bilobata, N. lanceolata, $N$. paradoxa, filiforms, N. longissima, Cymbella cuspidata, C. lata, Synedra ulna, Cyclotella meneghiniana, Tabellaria fenestrate, Cocconeis placentula, and Pinnularia major are organic pollution indicator species and were present at both tides [51-56]. These species signified that Okpoka Creek is under stress or suggested organic pollution at both tides from anthropogenic inputs from the surrounding industries and waterfront dwellers. Also, the presence of these species might 


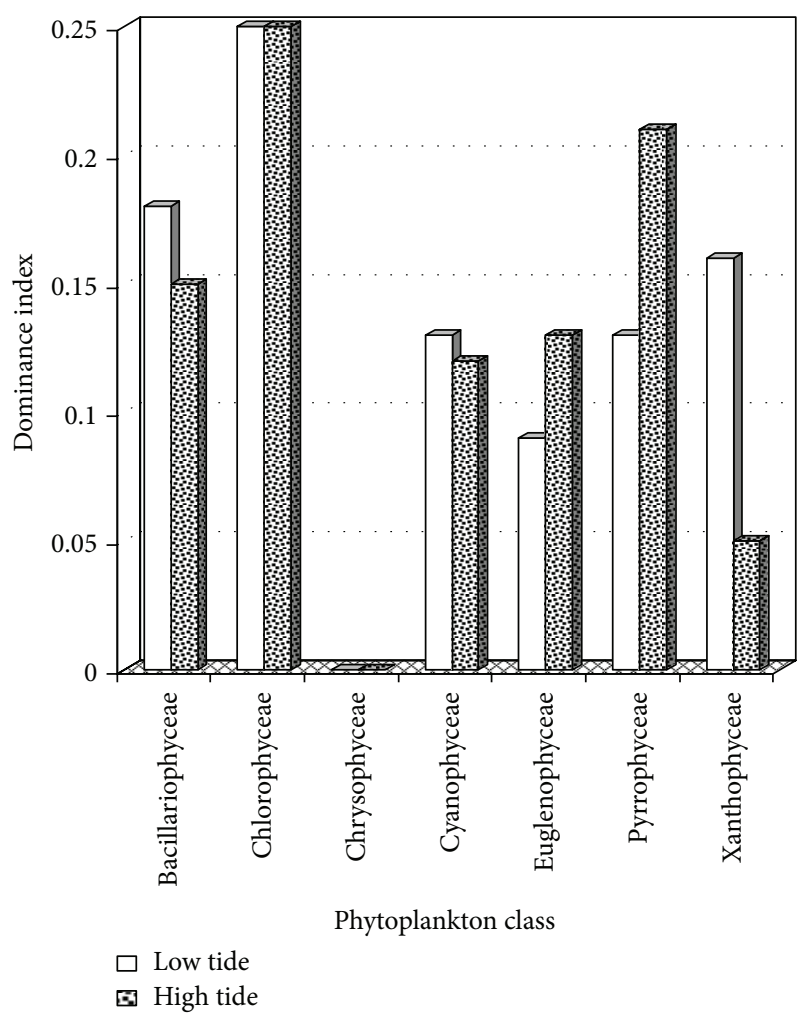

FIGURE 7: Variation of phytoplankton dominance index. Variations of phytoplankton parameters in relation to tide in Okpoka Creek.

further highlight inefficient disposal of domestic wastes in this creek. Nitzschia lanceolata, N. filiforms, N. longissima, N. spp., Navicula amphibola, and N. spp. were present only at high tide while Tabellaria fenestrate, Cymbella cuspidata, Pinnularia major, $N$. paradoxa, Navicula gracilis, $N$. cuspidata, $N$. placentula, and N. microcephala were significantly abundant at high tide. Cyclotella meneghiniana was not significantly abundant at both tides but higher at high tide. This showed that these species exhibit migratory behaviour which is aided by passive transport. Cocconeis placentula was present only at low tide while Synedra ulna, Nitzschia bilobata, and Navicula bacillum were significantly abundant at low tide. Nitzschia sigma was insignificantly abundant at both tides but higher at low tide. Advection cycle, settling, and resuspension that follow the suspended particles during the ebb, slack, and flood tidal stages may explain this observation. These species could be autochthonous phytoplankton so they were able to remain and possibly grew at a very high rate at low tide. Autochthonous phytoplankton population has the ability to maintain itself within an estuarine segment and is determined mainly by its rate of growth relative to the proportion of population biomass lost through flushing from the segment during each tidal cycle [4]. Phytoplankton organisms may also use the capacity to grow at very high rates as a physiological response in order to compensate for advective losses during the ebb tide. Diatoms have the capacity for rapid cell division with growth rates (up to $5.9 \mathrm{day}^{-1}$ ). The flushing action of the tidal flows contributed to movement of pollutants (discharged into estuary by industries concentrated along it) down into the Okpoka Creek. Tide had significant effect on similarity index $(P<0.05, \mathrm{DMR})$, higher at low tide $(70.58 \pm$ $2.20 \%)$ than at high tide $(59.35 \pm 4.10 \%)$. This showed that diatoms were similarly distributed at low tide (Table 4).

4.4. Chlorophyceae (Green Algae). Green algae density ranged between $1655.08 \pm 126.62 \mathrm{no} / \mathrm{mL}$ (low tide) and $1729.59 \pm 204.6 \mathrm{no} / \mathrm{mL}$ (high tide) with a mean of $1672.97 \pm$ $107.89 \mathrm{no} / \mathrm{mL}$ which was $14.68 \%$ total phytoplankton abundance. Tide had significant impact on parameters except density and Dominance index $(P<0.05)$. The insignificant tidal differences in the density and dominance species index might be that the passive drifting of green algae from the sea into the Okpoka Creek via the Upper Bonny Estuary was probably low. These further suggested that tide had little or no effect on green algae populations. Also, it might be that the green algae of the Upper Bonny Estuary are environment selective or low in abundance. Diversity indices varied between low and high tides as follows: Margalef $(0.52 \pm 0.50$ and $0.67 \pm 0.51)$, Shannon ( $0.30 \pm 0.02$ and $0.37 \pm 0.03)$, Evenness $(0.27 \pm 0.01$ and $0.33 \pm 0.02)$, and Dominance $(0.25 \pm 0.01$ and $0.25 \pm 0.02)$.

Nine genera and 10 species out of the 44 observed green algae species were abundant (Table 5). The species were as follows: Coelochaeta nitellarum (76.16 $\pm 16.16 \%)$, Netrium digitus (44.19 $\pm 4.72 \%)$, Draparnaldia sp. (42.392 \pm $1.92 \%)$, Entransia dichloroplastes (23.85 $\pm 16.16 \%)$, Crucigenia fenestrata $(36.39 \pm 2.70 \%)$, Bulbochaeta sp. $(20.48 \pm 12.86 \%)$, Gonatozygon aculeatum (29.69 $\pm 3.23 \%)$, Microspora villena $(22.35 \pm 2.33 \%), C$. rectangularis $(21.47 \pm 2.83 \%)$, and Coelastrum microsporum $(20.04 \pm 9.14 \%)$. Tidal effects on these green algae were different $(P<0.05)$. It was observed that Coleochaete nitellarum, E. dichloroplastes, Gonatozygon aculeatum, Netrium digitus, and Bulbochaeta sp. were present only at low tide while $C$. fenestrata and Microspora villeana were significantly present at both tides $(P<0.05)$ but their abundances were higher at low tide. This probably signified that at high tide, these dominant green algae species might rarely drift into the creek thus the higher percentage distributions at low tide. The variation of abundant of Draparnaldia sp., C. rectangularis, and Coelastrum microsporum were significantly higher at high tide than low tide. The presence of Cladophora glomerata (especially at low tide) and Scenedesmus species (only at low tide) confirms the polluted nature of Okpoka Creek and agrees with Nwankwo and Akinsoji [51] that C. glomerata is tolerant to organic pollution and weak salinity. Weak salinity is expected at low tide as there is no inflow of sea water into the Okpoka Creek via the Bonny Estuary. The mean species similarity index of $43.60 \pm 2.92 \%$ and dissimilarity index of $56.40 \pm 2.90 \%$ were recorded. Green algae species were similarly distributed at both tides.

4.5. Cyanophyceae (Blue-Green Algae). Cyanophytes ranged from $369.47 \pm 31.52 \mathrm{no} / \mathrm{mL}$ (low tide) to $418.18 \pm 53.31 \mathrm{no} /$ $\mathrm{mL}$ (high tide) with a mean of $382.31 \pm 27.10 \mathrm{no} / \mathrm{mL}$ and represented $3.36 \%$ of the phytoplankton population. 
TABLE 3: Variations of Bacillariophyceae species under tidal influence in Okpoka Creek.

\begin{tabular}{|c|c|c|c|c|c|}
\hline \multirow{2}{*}{ S/no. } & \multirow{2}{*}{ Species } & \multicolumn{3}{|c|}{ Means \pm SEM (\%) } & \multirow{2}{*}{ Statistical difference (ANOVA) } \\
\hline & & Overall & Low tide & High tide & \\
\hline 1 & Cyclotella comta & $10.89 \pm 1.32$ & $11.26 \pm 1.54^{\mathrm{a}}$ & $8.91 \pm 1.22^{\mathrm{b}}$ & $P<0.05$ \\
\hline 2 & C. meneghiniana & $9.34 \pm 0.97$ & $9.34 \pm 1.14^{\mathrm{a}}$ & $9.36 \pm 1.94^{\mathrm{a}}$ & $P>0.05$ \\
\hline 3 & C. striata & $7.31 \pm 1.24$ & $5.96 \pm 1.36^{\mathrm{b}}$ & $8.65 \pm 2.02^{\mathrm{a}}$ & $P>0.05$ \\
\hline 4 & C. operculata & $17.24 \pm 1.63$ & $17.03 \pm 1.98^{\mathrm{a}}$ & $18.33 \pm 0.00^{\mathrm{a}}$ & $P>0.05$ \\
\hline 5 & C. species* & $3.96 \pm 0.32$ & $3.96 \pm 0.32$ & - & \\
\hline 6 & Fragilaria intermedia & $1.94 \pm 0.54$ & $1.85 \pm 0.32^{\mathrm{a}}$ & $2.12 \pm 1.91^{\mathrm{a}}$ & $P>0.05$ \\
\hline 7 & F. capucina & $2.66 \pm 1.59$ & $2.66 \pm 1.59$ & - & \\
\hline 8 & F. construens & $0.39 \pm 0.00$ & - & $0.39 \pm 0.00$ & \\
\hline 9 & F. species* & $3.02 \pm 0.00$ & - & $3.02 \pm 0.00$ & \\
\hline 10 & Epithermia zebra & $0.47 \pm 0.00$ & $0.47 \pm 0.00$ & - & \\
\hline 11 & Attheya zacharias & $0.79 \pm 0.00$ & - & $0.79 \pm 0.00$ & \\
\hline 12 & Stauroneis acuta & $3.21 \pm 0.00$ & $3.21 \pm 0.00$ & - & \\
\hline 13 & S. parvula & $2.71 \pm 0.00$ & - & $2.71 \pm 0.00$ & \\
\hline 14 & S. species ${ }^{*}$ & $1.97 \pm 0.00$ & - & $4.36 \pm 1.03$ & \\
\hline 15 & Diatoma vulgare & $4.35 \pm 0.77$ & $4.33 \pm 1.21^{\mathrm{a}}$ & $0.65 \pm 0.36^{b}$ & $P<0.05$ \\
\hline 16 & Rhizosolenia sp. & $0.65 \pm 0.36$ & - & $1.69 \pm 0.34$ & \\
\hline 17 & Tabellaria fenestrate & $1.62 \pm 0.26$ & $1.34 \pm 0.02^{\mathrm{b}}$ & $12.81 \pm 1.84^{\mathrm{a}}$ & $P<0.05$ \\
\hline 18 & Synedria ulna & $12.08 \pm 1.71$ & $8.80 \pm 4.64^{\mathrm{a}}$ & $3.82 \pm 0.00^{\mathrm{b}}$ & $P<0.05$ \\
\hline 19 & S. acus & $4.51 \pm 0.69$ & $5.19 \pm 0.00^{\mathrm{b}}$ & $8.33 \pm 1.41^{\mathrm{a}}$ & $P<0.05$ \\
\hline 20 & S. affinis & $7.29 \pm 1.55$ & $2.12 \pm 0.00^{\mathrm{b}}$ & $8.81 \pm 1.27^{\mathrm{a}}$ & $P<0.05$ \\
\hline 21 & S. species* & $10.26 \pm 1.26$ & $14.14 \pm 1.96^{\mathrm{a}}$ & $9.90 \pm 1.22^{\mathrm{b}}$ & $P<0.05$ \\
\hline 22 & Coscinodiscus lacustris & $9.46 \pm 1.00$ & $7.81 \pm 1.52^{\mathrm{a}}$ & $5.64 \pm 1.55^{\mathrm{b}}$ & $P<0.05$ \\
\hline 23 & C. radiate & $6.39 \pm 1.18$ & $7.90 \pm 1.71^{\mathrm{a}}$ & $0.96 \pm 0.00^{\mathrm{b}}$ & $P<0.05$ \\
\hline 24 & C. excentricus & $0.96 \pm 0.00$ & - & $7.41 \pm 6.61$ & \\
\hline 25 & C. species* & $7.41 \pm 6.61$ & - & $2.53 \pm 0.66$ & \\
\hline 26 & Amphora ovalis & $2.68 \pm 0.54$ & $3.17 \pm 0.86^{\mathrm{b}}$ & $15.48 \pm 1.76^{\mathrm{a}}$ & $P<0.05$ \\
\hline 27 & Nitzschia sigma & $15.15 \pm 1.64$ & $11.84 \pm 4.46^{\mathrm{a}}$ & $10.16 \pm 2.78^{\mathrm{a}}$ & $P>0.05$ \\
\hline 28 & N. bilobata & $11.39 \pm 1.95$ & $13.86 \pm 1.55^{\mathrm{a}}$ & $8.50 \pm 2.45^{\mathrm{b}}$ & $P<0.05$ \\
\hline 29 & N. lanceolata & $8.50 \pm 2.45$ & - & $6.64 \pm 0.70$ & \\
\hline 30 & N. paradoxa & $6.83 \pm 0.60$ & $7.75 \pm 0.00^{\mathrm{b}}$ & $11.33 \pm 0.85^{\mathrm{a}}$ & $P<0.05$ \\
\hline 31 & N. filiforms & $11.33 \pm 0.85$ & - & $10.17 \pm 0.00$ & \\
\hline 32 & N. longissima & $10.17 \pm 0.00$ & - & $7.08 \pm 3.47$ & \\
\hline 33 & N. species* & $7.08 \pm 3.47$ & - & $8.06 \pm 1.60$ & \\
\hline 34 & Navicula gracilis & $7.15 \pm 1.54$ & $3.49 \pm 0.00^{\mathrm{b}}$ & $11.29 \pm 1.73^{\mathrm{a}}$ & $P<0.05$ \\
\hline 35 & N. cuspidata & $10.74 \pm 1.60$ & $6.91 \pm 0.00^{\mathrm{b}}$ & $10.21 \pm 0.71^{\mathrm{a}}$ & $P<0.05$ \\
\hline 36 & N. placentula & $10.09 \pm 0.60$ & $9.53 \pm 1.07^{\mathrm{b}}$ & $12.41 \pm 1.11^{\mathrm{a}}$ & $P<0.05$ \\
\hline 37 & N. microcephala & $10.33 \pm 1.72$ & $7.21 \pm 3.09^{\mathrm{b}}$ & $10.18 \pm 2.11^{\mathrm{a}}$ & $P<0.05$ \\
\hline 38 & N. bacillum & $11.37 \pm 1.18$ & $12.55 \pm 1.06^{\mathrm{a}}$ & $0.37 \pm 0.00^{\mathrm{b}}$ & $P<0.05$ \\
\hline 39 & N. amphibola & $0.37 \pm 0.00$ & - & $9.53 \pm 2.95$ & \\
\hline 40 & N. species* & $9.53 \pm 2.95$ & - & $13.14 \pm 0.73$ & \\
\hline 41 & Melosira varians & $12.54 \pm 0.73$ & $10.13 \pm 2.07^{\mathrm{b}}$ & $26.03 \pm 16.05^{\mathrm{a}}$ & $P>0.05$ \\
\hline 42 & M. undulate & $26.03 \pm 16.05$ & - & $17.66 \pm 0.96$ & \\
\hline 43 & M. pusilla & $17.66 \pm 0.96$ & - & $14.62 \pm 5.73$ & \\
\hline 44 & M. distans & $12.16 \pm 4.13$ & $7.23 \pm 0.00^{\mathrm{a}}$ & $7.85 \pm 0.25^{\mathrm{a}}$ & $P>0.05$ \\
\hline 45 & M. listans & $9.08 \pm 0.99$ & $10.92 \pm 2.01$ & - & \\
\hline 46 & M. granulate & $1.60 \pm 0.00$ & $1.60 \pm 0.00^{\mathrm{a}}$ & $0.77 \pm 0.00^{\mathrm{a}}$ & $P>0.05$ \\
\hline
\end{tabular}


TABLE 3: Continued.

\begin{tabular}{|c|c|c|c|c|c|}
\hline \multirow{2}{*}{ S/no. } & \multirow{2}{*}{ Species } & \multicolumn{3}{|c|}{ Means \pm SEM (\%) } & \multirow{2}{*}{ Statistical difference (ANOVA) } \\
\hline & & Overall & Low tide & High tide & \\
\hline 47 & M. species* & $0.77 \pm 0.00$ & - & $3.16 \pm 0.01$ & \\
\hline 48 & Cymbella cuspidata & $2.34 \pm 0.82$ & $0.70 \pm 0.00^{\mathrm{b}}$ & $2.20 \pm 0.00^{\mathrm{a}}$ & $P<0.05$ \\
\hline 49 & C. lata & $2.20 \pm 0.00$ & - & $3.59 \pm 0.01$ & \\
\hline 50 & Asterionella formosa & $0.84 \pm 0.00$ & $0.84 \pm 10.00^{\mathrm{b}}$ & $2.41 \pm 0.00^{\mathrm{a}}$ & $P<0.05$ \\
\hline 51 & Surirella species* & $2.41 \pm 0.00$ & - & $1.94 \pm 0.00$ & \\
\hline 52 & S. tenera & $1.25 \pm 0.70$ & $0.55 \pm 0.00$ & $0.99 \pm 0.00$ & \\
\hline 53 & S. elegans & $0.99 \pm 0.00$ & - & $4.66 \pm 2.25$ & \\
\hline 54 & S. robusta & $5.49 \pm 2.08$ & $10.48 \pm 0.00^{\mathrm{a}}$ & $0.27 \pm 0.00^{\mathrm{b}}$ & $P<0.05$ \\
\hline 55 & Cymatopleura species* & $0.27 \pm 0.00$ & - & $1.16 \pm 0.00$ & \\
\hline 56 & Campylodiscus hibernicus & $1.16 \pm 0.00$ & - & $2.30 \pm 1.18$ & \\
\hline 57 & Pinnularia viridis & $2.03 \pm 0.73$ & - & $1.75 \pm 0.30$ & \\
\hline 58 & P. horealis & $2.90 \pm 0.82$ & $4.05 \pm 1.39^{\mathrm{a}}$ & $0.56 \pm 0.21^{\mathrm{b}}$ & $P<0.05$ \\
\hline 59 & P. major & $0.87 \pm 0.33$ & $1.49 \pm 0.00^{\mathrm{b}}$ & $6.69 \pm 1.10^{\mathrm{a}}$ & $P<0.05$ \\
\hline 60 & P. species* & $6.69 \pm 1.10$ & - & $7.00 \pm 1.12$ & \\
\hline 61 & Frustulia rhomboides & $7.35 \pm 0.96$ & $8.40 \pm 2.04^{\mathrm{a}}$ & $7.08 \pm 0.81^{\mathrm{a}}$ & $P>0.05$ \\
\hline 62 & Gyrosigma acuminatum & $7.24 \pm 0.75$ & $7.76 \pm 1.88^{\mathrm{b}}$ & $15.76 \pm 0.00^{\mathrm{a}}$ & $P<0.05$ \\
\hline 63 & G. species* & $15.76 \pm 0.00$ & - & $11.46 \pm 0.00$ & \\
\hline 64 & G. attenuatum & $11.46 \pm 0.00$ & - & $3.53 \pm 0.00$ & \\
\hline 65 & G. paradoxa & $3.53 \pm 0.00$ & - & $5.61 \pm 1.08$ & \\
\hline 66 & Stephanodiscus astraea & $6.10 \pm 1.07$ & $9.98 \pm 0.00$ & - & \\
\hline 67 & S. species* & $1.70 \pm 0.00$ & $1.70 \pm 0.00$ & - & \\
\hline 68 & Cocconeis placentula & $0.38 \pm 0.00$ & $0.38 \pm 0.00$ & - & \\
\hline 69 & Bacteriastrum & $0.10 \pm 0.00$ & $0.10 \pm 0.00$ & - & \\
\hline 70 & Bacillaria species* & $1.57 \pm 0.00$ & $1.52 \pm 0.00$ & - & \\
\hline 71 & Biddulphia species* & $0.30 \pm 0.00$ & $0.30 \pm 0.00$ & - & \\
\hline 72 & Corethron hystrix & $10.82 \pm 0.00$ & $10.82 \pm 0.00$ & - & \\
\hline 73 & Cylindrotheca species* & $4.67 \pm 0.00$ & $4.67 \pm 0.00$ & - & \\
\hline 74 & C. gracilis & $2.67 \pm 0.00$ & $2.67 \pm 0.00$ & - & \\
\hline 75 & Diploneis species* & $0.07 \pm 0.00$ & $0.07 \pm 0.00$ & - & \\
\hline 76 & Ditylum species* & $0.10 \pm 0.00$ & $0.10 \pm 0.00$ & - & \\
\hline 77 & Hydrosera species* & $1.00 \pm 0.00$ & $1.00 \pm 0.00$ & - & \\
\hline 78 & Skeletonema species* & $0.84 \pm 0.00$ & $0.84 \pm 0.00$ & - & \\
\hline 79 & Thalassiothrix species* & $0.13 \pm 0.00$ & $0.13 \pm 0.00$ & - & \\
\hline 80 & T. longissimum & $0.17 \pm 0.00$ & $0.17 \pm 0.00$ & - & \\
\hline
\end{tabular}

Means with the same letter in the same row are not significantly different $(P>0.05)$.

${ }^{*}$ Means unidentified; - : absent.

TABLE 4: Variations of phytoplankton similarity and dissimilarity indices in relation to tide in Okpoka Creek.

\begin{tabular}{|c|c|c|c|c|c|c|c|}
\hline Tide & Bacillariophyceae & Chlorophyceae & Cyanophyceae & Xantophyceae & Pyrrophyceae & Chrysophyceae & Euglenophyceae \\
\hline \multicolumn{8}{|c|}{ Similarity index (\%) } \\
\hline Low & $70.58 \pm 2.20^{\mathrm{a}}$ & $43.75 \pm 3.40^{\mathrm{a}}$ & $17.38 \pm 3.44^{\mathrm{a}}$ & $38.68 \pm 5.57^{\mathrm{a}}$ & $12.32 \pm 4.85^{\mathrm{b}}$ & $17.24 \pm 7.14^{\mathrm{a}}$ & $9.82 \pm 4.19^{\mathrm{a}}$ \\
\hline High & $59.35 \pm 4.10^{\mathrm{b}}$ & $43.08 \pm 5.61^{\mathrm{a}}$ & $21.71 \pm 6.94^{\mathrm{a}}$ & $13.40 \pm 7.16^{\mathrm{a}}$ & $40.00 \pm 24.50^{\mathrm{a}}$ & $00.00 \pm 0.00^{\mathrm{a}}$ & $9.57 \pm 6.50^{\mathrm{a}}$ \\
\hline \multicolumn{8}{|c|}{ Dissimilarity index (\%) } \\
\hline Low & $29.42 \pm 2.15^{\mathrm{b}}$ & $56.25 \pm 3.39^{\mathrm{a}}$ & $82.62 \pm 3.43^{\mathrm{a}}$ & $61.32 \pm 5.62^{\mathrm{a}}$ & $87.68 \pm 6.86^{\mathrm{a}}$ & $82.76 \pm 7.14^{\mathrm{a}}$ & $90.18 \pm 6.87^{\mathrm{a}}$ \\
\hline High & $40.65 \pm 4.10^{\mathrm{a}}$ & $56.92 \pm 5.61^{\mathrm{a}}$ & $78.29 \pm 6.94^{\mathrm{a}}$ & $86.60 \pm 7.16^{\mathrm{a}}$ & $60.00 \pm 24.50^{\mathrm{a}}$ & $100.00 \pm 0.00^{\mathrm{a}}$ & $90.43 \pm 5.58^{\mathrm{a}}$ \\
\hline
\end{tabular}

Means with the same letter in the same column are not significantly different $(P>0.05)$. 
TABLE 5: Variations of Chlorophyceae species under tidal influence in Okpoka Creek.

\begin{tabular}{|c|c|c|c|c|c|}
\hline \multirow{2}{*}{ S/no. } & \multirow{2}{*}{ Species } & \multicolumn{3}{|c|}{ Means \pm SEM (\%) } & \multirow{2}{*}{ Statistical difference (ANOVA) } \\
\hline & & Overall & Low tide & High tide & \\
\hline 1 & Microspora villeana & $22.35 \pm 2.33$ & $23.15 \pm 2.89^{\mathrm{a}}$ & $19.18 \pm 0.61^{b}$ & $P<0.05$ \\
\hline 2 & Spirotaenia species ${ }^{*}$ & $11.88 \pm 4.12$ & $11.88 \pm 4.12$ & - & \\
\hline 3 & Coelochaeta nitellarum & $76.16 \pm 16.16$ & $76.16 \pm 16.16$ & - & \\
\hline 4 & Mesotaenium species ${ }^{*}$ & $16.08 \pm 8.17$ & $26.55 \pm 13.46^{\mathrm{a}}$ & $5.59 \pm 0.24^{\mathrm{b}}$ & $P<0.05$ \\
\hline 5 & Entransia dichloroplastes & $23.85 \pm 16.16$ & $23.85 \pm 16.16$ & - & \\
\hline 6 & Chactosphora species* & $1.47 \pm 0.00$ & $1.47 \pm 0.00$ & - & \\
\hline 7 & Tetraedron tumidulum & $7.53 \pm 2.51$ & $8.48 \pm 3.04^{\mathrm{a}}$ & $3.76 \pm 2.45^{b}$ & $P<0.05$ \\
\hline 8 & Tetmemorus species* & $1.77 \pm 0.00$ & - & $1.77 \pm 0.00$ & \\
\hline 9 & Penium species* & $2.07 \pm 0.00$ & $2.07 \pm 0.00$ & - & \\
\hline 10 & Crucigenia rectangularis & $21.47 \pm 2.83$ & $18.13 \pm 2.03^{\mathrm{b}}$ & $28.15 \pm 6.81^{\mathrm{a}}$ & $P<0.05$ \\
\hline 11 & C. fenestrate & $36.39 \pm 2.70$ & $37.62 \pm 2.73^{\mathrm{a}}$ & $26.56 \pm 0.00^{\mathrm{b}}$ & $P<0.05$ \\
\hline 12 & C. puadrata & $13.65 \pm 3.62$ & $12.66 \pm 4.92^{\mathrm{b}}$ & $16.61 \pm 0.00^{\mathrm{a}}$ & $P<0.05$ \\
\hline 13 & Gonatozygon aculeatum & $29.69 \pm 3.23$ & $29.69 \pm 3.23$ & - & \\
\hline 14 & G. species* & $12.18 \pm 6.39$ & $12.18 \pm 6.39$ & - & \\
\hline 15 & Staurastrum grande & $5.90 \pm 2.21$ & $7.36 \pm 2.88^{\mathrm{a}}$ & $2.99 \pm 0.00^{b}$ & $P<0.05$ \\
\hline 16 & S. natator & $14.29 \pm 0.00$ & $14.29 \pm 0.00^{\mathrm{a}}$ & $6.18 \pm 0.02^{b}$ & $P<0.05$ \\
\hline 17 & Closterium dianae & $6.18 \pm 0.02$ & - & $21.59 \pm 0.92$ & \\
\hline 18 & C. parvulum & $16.16 \pm 2.49$ & $10.74 \pm 2.92^{\mathrm{a}}$ & $7.21 \pm 2.12^{b}$ & $P<0.05$ \\
\hline 19 & C. gracile & $7.81 \pm 1.75$ & $10.19 \pm 2.11^{\mathrm{a}}$ & $2.36 \pm 0.00^{\mathrm{b}}$ & $P<0.05$ \\
\hline 20 & C. kuetzingii & $2.36 \pm 0.00$ & - & $1.81 \pm 0.00$ & \\
\hline 21 & C. macilentus & $1.81 \pm 0.00$ & - & $4.72 \pm 0.00$ & \\
\hline 22 & C. strigosum & $4.72 \pm 0.00$ & - & $5.01 \pm 0.01$ & \\
\hline 23 & Cosmarium species* & $7.14 \pm 0.00$ & $7.14 \pm 0.00^{\mathrm{b}}$ & $20.00 \pm 0.00^{\mathrm{a}}$ & $P<0.05$ \\
\hline 24 & C. granatum & $11.40 \pm 8.60$ & $2.80 \pm 0.00^{\mathrm{b}}$ & $13.42 \pm 0.00^{\mathrm{a}}$ & $P<0.05$ \\
\hline 25 & Cladophora glomerata & $15.94 \pm 2.52$ & $18.45 \pm 0.00^{\mathrm{a}}$ & $9.73 \pm 5.55^{b}$ & $P<0.05$ \\
\hline 26 & C. elegans & $12.21 \pm 2.98$ & $14.69 \pm 2.71^{\mathrm{b}}$ & $64.99 \pm 30.82^{\mathrm{a}}$ & $P<0.05$ \\
\hline 27 & Draparnaldia species* & $42.39 \pm 21.92$ & $8.50 \pm 6.47^{b}$ & $24.89 \pm 18.58^{\mathrm{a}}$ & $P<0.05$ \\
\hline 28 & Coelastrum microporum & $20.04 \pm 9.14$ & $15.80 \pm 10.95^{\mathrm{b}}$ & $18.96 \pm 3.96^{\mathrm{a}}$ & $P<0.05$ \\
\hline 29 & C. recticulatum & $16.62 \pm 3.28$ & $8.82 \pm 2.44^{\mathrm{b}}$ & $13.33 \pm 0.00^{\mathrm{a}}$ & $P<0.05$ \\
\hline 30 & Rhizodonium hookeri & $12.98 \pm 0.36$ & $12.62 \pm 0.00^{\mathrm{a}}$ & $1.01 \pm 0.00^{\mathrm{b}}$ & $P<0.05$ \\
\hline 31 & Desmidium grevillii & $1.52 \pm 0.51$ & $2.03 \pm 0.00^{\mathrm{b}}$ & $11.53 \pm 2.29^{\mathrm{a}}$ & $P<0.05$ \\
\hline 32 & D. aptogonum & $8.62 \pm 3.19$ & $2.80 \pm 0.00^{\mathrm{b}}$ & $5.09 \pm 0.00^{\mathrm{a}}$ & $P<0.05$ \\
\hline 33 & Planktosphaeria gelatinosa & $5.21 \pm 0.12$ & $5.33 \pm 0.00^{\mathrm{b}}$ & $43.71 \pm 5.06^{\mathrm{a}}$ & $P<0.05$ \\
\hline 34 & Netrium digitus & $44.19 \pm 4.72$ & $1.72 \pm 0.00$ & - & \\
\hline 35 & Treubaria crassispina & $1.72 \pm 0.00$ & $20.48 \pm 12.86$ & - & \\
\hline 36 & Bulbochaeta species* & $20.48 \pm 12.86$ & $12.90 \pm 0.44$ & - & \\
\hline 37 & Clostridium lunula & $12.90 \pm 0.44$ & $7.62 \pm 0.00$ & - & \\
\hline 38 & Docidium species* $^{*}$ & $7.62 \pm 0.00$ & $44.44 \pm 0.00$ & - & \\
\hline 39 & Ankistrodesmus species* & $44.44 \pm 0.00$ & $7.41 \pm 0.00$ & - & \\
\hline 40 & Oedogonium species* & $7.41 \pm 0.00$ & $38.33 \pm 0.00$ & - & \\
\hline 41 & Scenedesmus species* ${ }^{*}$ & $38.33 \pm 0.00$ & $14.82 \pm 0.00$ & - & \\
\hline 42 & Spirogyra species* & $14.82 \pm 0.00$ & $2.07 \pm 0.00$ & - & \\
\hline 43 & Cladophora species* & $2.07 \pm 0.00$ & $17.15 \pm 2.86$ & - & \\
\hline 44 & Netrium species ${ }^{*}$ & $17.15 \pm 2.86$ & $18.05 \pm 3.05$ & - & \\
\hline
\end{tabular}

Means with the same letter in the same row are not significantly different $(P>0.05)$.

${ }^{*}$ Means unidentified; —: absent. 


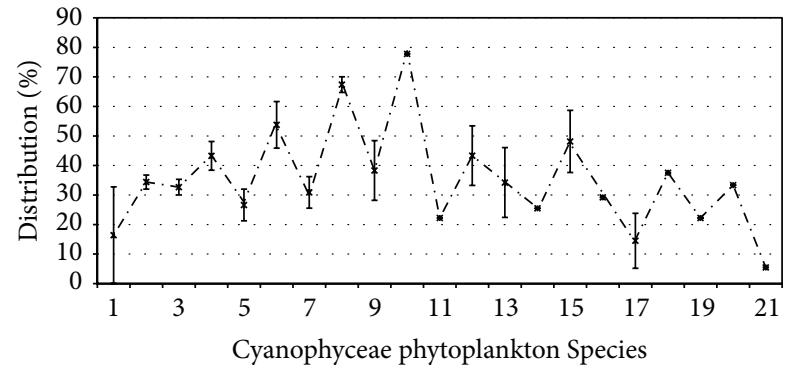

FIgURE 8: Overall mean values of Cyanophyceae species in Okpoka Creek. $(1=A$. sp, $2=$ A. affinis, $3=$ A. arnoldii, $4=A$. spiroides, $5=A$. arnoldii, $6=$ S. subsalsa, $7=$ S. laxissima, $8=S$. major, $9=$ S. princeps, $10=M$. pulverea, $11=0$. princeps, $12=0$. lacustris, $13=0$. tenuis, $14=$ O. $s p, 15=R . s p, 16=$ L. hieronymussi, $17=$ L. limnetica, $18=$ L. major , $19=$ R. curvata, $20=$ P. musicola, and $21=$ N. sp).

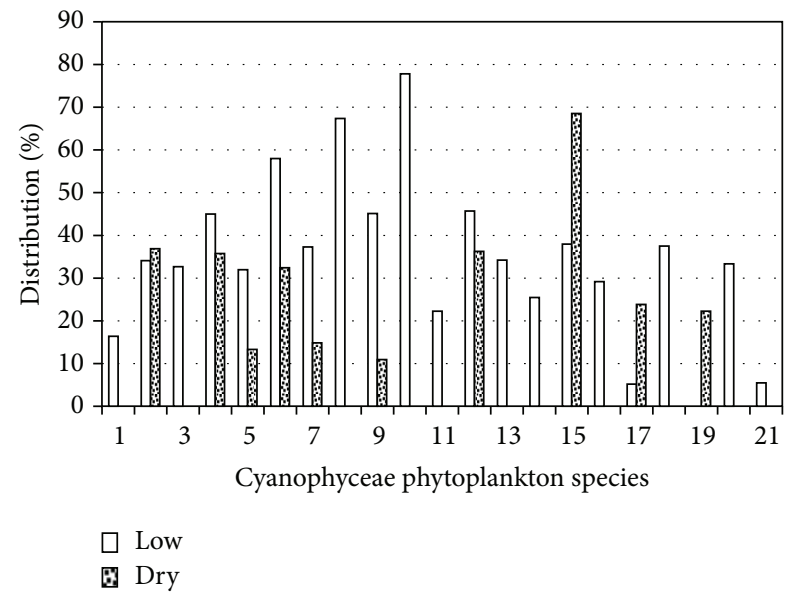

FIGURE 9: Variation of Cyanophyceae species in relation to tide in Okpoka Creek. $(1=$ A. $s p, 2=$ A. affinis, $3=$ A. arnoldii, $4=A$. spiroides, $5=A$. arnoldii, $6=S$. subsalsa, $7=S$. laxissima, $8=S$. major, $9=S$. princeps, $10=M$. pulverea, $11=0$. princeps, $12=0$. lacustris, $13=$ O. tenuis, $14=O . s p, 15=R . s p, 16=L$. hieronymussi, $17=L$. limnetica, $18=$ L. major, $19=R$. curvata, $20=P$. musicola , and $21=$ N. sp).

The ANOVA for these phytoplankton parameters showed insignificant difference $(P>0.05)$. The insignificant higher density of blue-green algae at high tide might be traced to inflow of these plants from the Upper Bonny Estuary into this creek. The slightly higher Margalef species richness and dominance index at low water showed that green algae species might have the ability to sink and settle vertically down within the water column; thus, they were retained in Okpoka Creek at low tide. Also, this observation might indicate a stable green algae community at low tide. From Figure 8, the dominant cyanophytes genera were Spirulina, Rivularia, Oscillatoria, and Anabaena. There were 10 salient species, namely; Spirulina major (67.39 $\pm 2.65 \%)$, S. subsalsa (53.72 \pm $7.90 \%)$, Rivularia sp (48.12 $\pm 10.51 \%)$, Oscillatoria lacustris (43.31 $\pm 10.10 \%)$, Anabaena spiroides, Spirulina princeps, (38.27 $\pm 10.11 \%)$, O. tenuis $(34.21 \pm 11.82 \%)$, and A. arnoldii $(32.65 \pm 2.65 \%)$. Tide had varied influence on these species. A. arnoldii, S. major and O. tenuis were only present at low tide. S. affinis, O. lacustris, and Rivularia sp were higher in

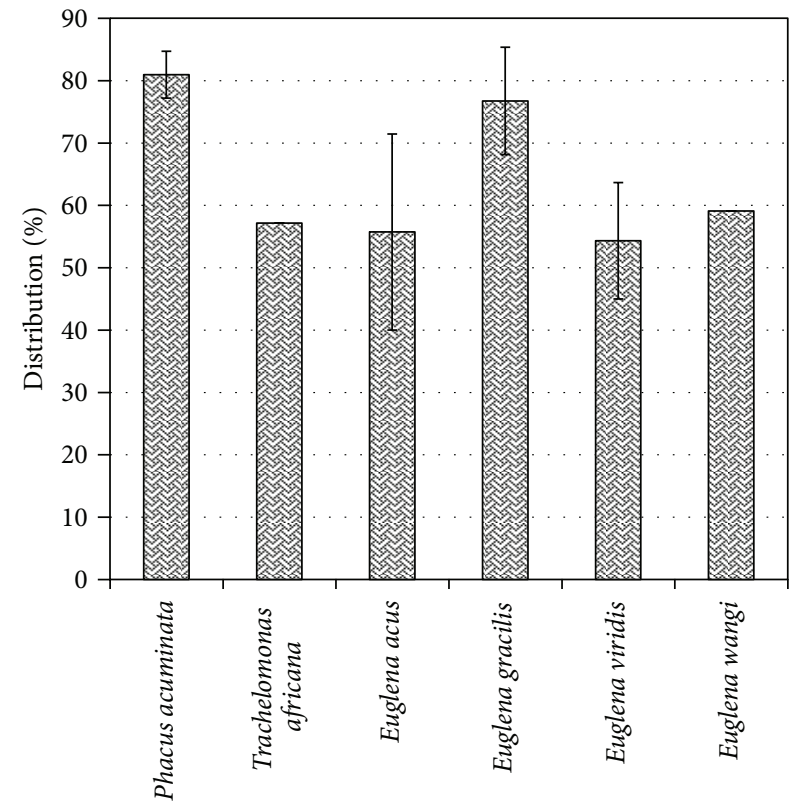

Euglenophyceae phytoplankton species

FIGURE 10: Overall mean values of Euglenophyceae species in Okpoka Creek.

distribution at high tide than at low tide while other species showed opposite response to tidal effect (Figure 9). Anabaena spiroides and Microcystis pulverea are pollution indicator species and were more abundant at low tide. These species are associated with eutrophic water bodies [56] and might have occurred in Okpoka Creek due to the increased influx of nutrients from anthropogenic inputs. Their presence at both tides except Microcystis pulverea could suggest pollution at both tides. At high tide, pollutants from the Upper Bonny Estuary moved into the creek while at low tide, pollutants from the different industries and residential buildings were pronounced. The mean species similarity index (18.41 \pm $3.08 \%)$ and dissimilarity index of $(81.59 \pm 33.49 \%)$ indicated different distributions of species at low and high tides. There was a higher insignificant dissimilarity index at low tide $(82.62 \pm 3.43 \%)$ than at high tide $(78.29 \pm 6.94 \%)(P>0.05)$.

4.6. Euglenophyceae (Euglenoid Flagellates). Euglenophyceae accounted for $0.85 \%$ (the least) of the phytoplankton population. Insignificant higher density of algae (105.74 \pm $19.55 \mathrm{no} / \mathrm{mL}$ ) was recorded at low tide than at high tide $(68.63 \pm 17.78 \mathrm{no} / \mathrm{mL})(P>0.05)$. Diversity indices were significantly higher at high tide than at low tide $(P<$ $0.05)$. Shannon index was insignificantly higher at low tide while evenness index was significantly higher at low tide $(P<0.05$, DMR $)$. This indicated that euglenoid species diversity was higher and unevenly distributed at high tide. This might be attributed to tidal turbulence owning to the inflow of sea water into the creek. Three genera and 6 species, namely, Phacus acuminata (80.95 $\pm 3.75 \%)$, Euglena gracilis $(76.74 \pm 8.61 \%)$, E. acus $(55.72 \pm 15.72 \%)$ E. viridis (54.32 $\pm 9.32 \%)$, E. wangi $(59.09 \pm 0.00 \%)$, and Trachelomonas africana $(57.14 \pm 0.00 \%)$ were observed (Figure 10). Tide 


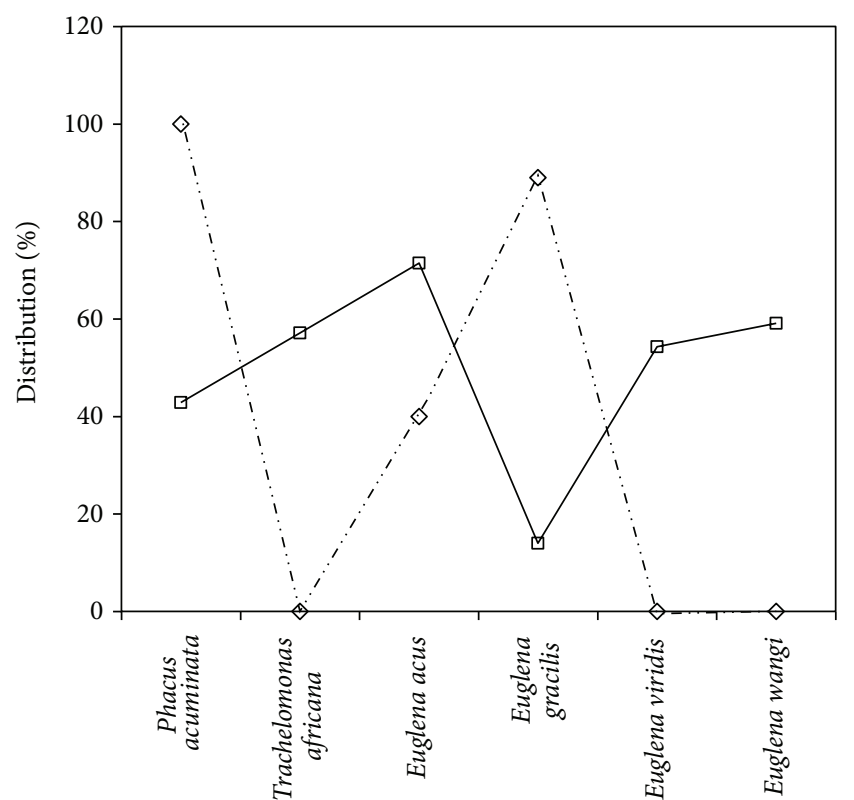

Euglenophyceae phytoplankton species

$$
\begin{array}{ll}
\diamond \cdots & \text { Low } \\
\square & \text { High }
\end{array}
$$

Figure 11: Variations of Euglenophyceae species in relation to tide in Okpoka Creek.

had significant different effects on these species $(P<0.05)$ (Figure 11).

P. acuminata and E. gracilis were higher at low tide than at high tide. T. africana, E. viridis and E. wangi were absent at low tide. Only one species (E. acus) was higher at high tide $(71.43 \pm 0.00 \%)$ than at low tide $(40.00 \pm 0.00 \%)$. E. acus, E. gracilis, E. viridis, E. wangi, and Phacus acuminata are implicated to organic matter. Organic matter and iron are implicated to be among the ecological factors that affect the euglenoids [51]. Pollution by dissolved organic nutrients is best interpreted by the saprobic system. The presence of higher abundance of $E$. acus at high tide might be a pointer that Okpoka Creek is undergoing deterioration especially at high water. The influx of sea water from the sea via the Bonny Estuary brings in effluents from the numerous industries and waterfront dwellers sited along the water course. The mean similarity index was $8.07 \pm 3.37 \%$ and dissimilarity index $91.93 \pm 4.59 \%$. Tide had no significant effect on similarity and dissimilarity indices. Species composition of euglenoid flagellates was dissimilar between the low tide (90.18 \pm $6.87 \%)$ and high tide $(90.43 \pm 5.58 \%)$.

4.7. Pyrrophyceae (Dinoflagellates). Dinoflagellates accounted for $2.52 \%$ of the phytoplankton abundance and ranged between $277.00 \pm 65.80 \mathrm{no} / \mathrm{mL}$ (low tide) and $314.57 \pm$ $117.99 \mathrm{no} / \mathrm{mL}$ (high tide) with a mean of $286.74 \pm 56.46 \mathrm{no} /$ $\mathrm{mL}$. Tidal influence on dinoflagellates parameters was insignificant $(P>0.05)$. Other parameters ranged between low tide and high tide as follows: Margalef $(0.19 \pm 0.09$ and $0.26 \pm 0.13)$, Shannon (0.08 \pm 0.03 and $0.13 \pm 0.06)$, Evenness

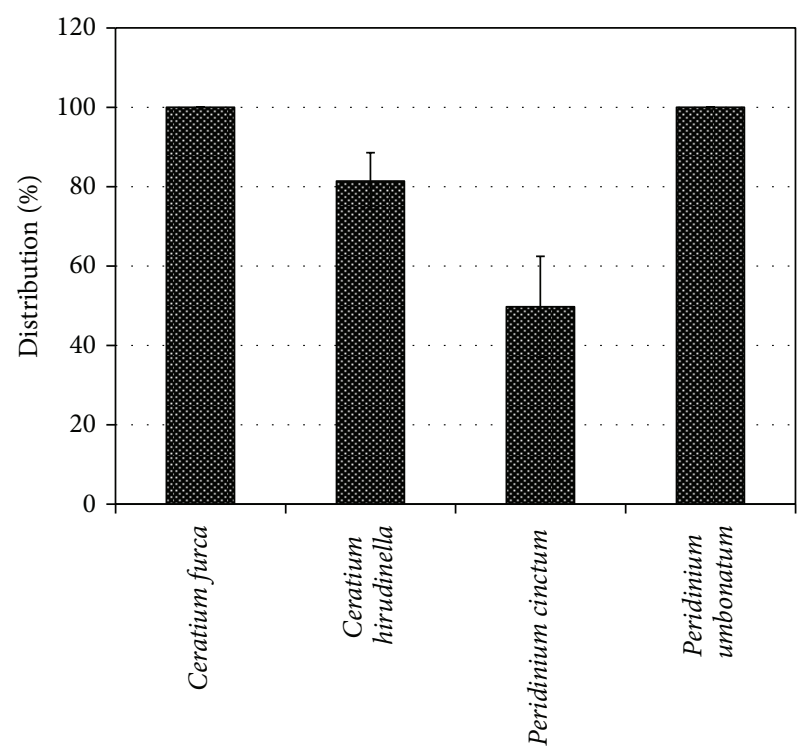

Pyrrophyceae phytoplankton species

Figure 12: Overall mean values of Pyrrophyceae species in Okpoka Creek.

$(0.12 \pm 0.05$ and $0.19 \pm 0.09)$, and Dominance $(0.13 \pm 0.05$ and $0.21 \pm 0.10)$. Two genera and 4 species of dinoflagellates were observed (Figure 12). They were Ceratium furca $(100.00 \pm 0.00 \%)$, C. hirudinella (81.42 $\pm 1.11 \%)$, Peridinium cinctum $(49.73 \pm 12.70 \%)$, and P. umbonatum $(100.00 \pm$ $0.00 \%$ ). Figure 13 shows that C. furca and P. umbonatum were present only at low tide. The absence of these species at high tide might probably be adduced to tidally phototactic vertical migration pattern and endogenous tidal rhythm [4]. Before high tide, these organisms disappeared, swimming down and attaching themselves to the dark underside of solid objects so as not to be affected by the high water or rise in water level. C. hirudinella distribution percentage was high at high tide $(80.44 \pm 19.57 \%)$ than at low tide $(81.75 \pm 8.29 \%)$. $P$. cinctum tidal mean ranged between $39.13 \pm 0.00 \%$ (high tide) and $52.38 \pm 16.03 \%$ (low tide). These species that were present at both tides could indicate resilience of these algae. The observed higher abundances of dinoflagellates at low tide could suggest passive transport process, and it is the main factor controlling the permanence of these species. In addition, the ability these algae to grow at a faster rate might be the possible reason. Dinoflagellates have the capacity for rapid cell division with growth rates up to 2.7 day $^{-1}$ based on equivalent body mass [4]. Ceratium furca has been implicated to organic pollution.

The mean similarity index ranged from $0.00 \pm 0.00 \%$ to $39.00 \pm 18.12 \%$ with a mean of $18.08 \pm 6.64 \%$, and dissimilarity index ranged from $61.00 \pm 18.12$ to $100.00 \pm$ $0.00 \%$ with a mean of $81.92 \pm 7.51 \%$. The ANOVA showed no significant differences. Tide had no significant effect on similarity and dissimilarity indices of dinoflagellates. Similarity index ranged between $12.32 \pm 4.85 \%$ (low tide) and $40.00 \pm 24.50 \%$ (high tide) while dissimilarity index was $60.00 \pm 24.50 \%$ (high tide) and $87.68 \pm 6.86 \%$ (low tide). 


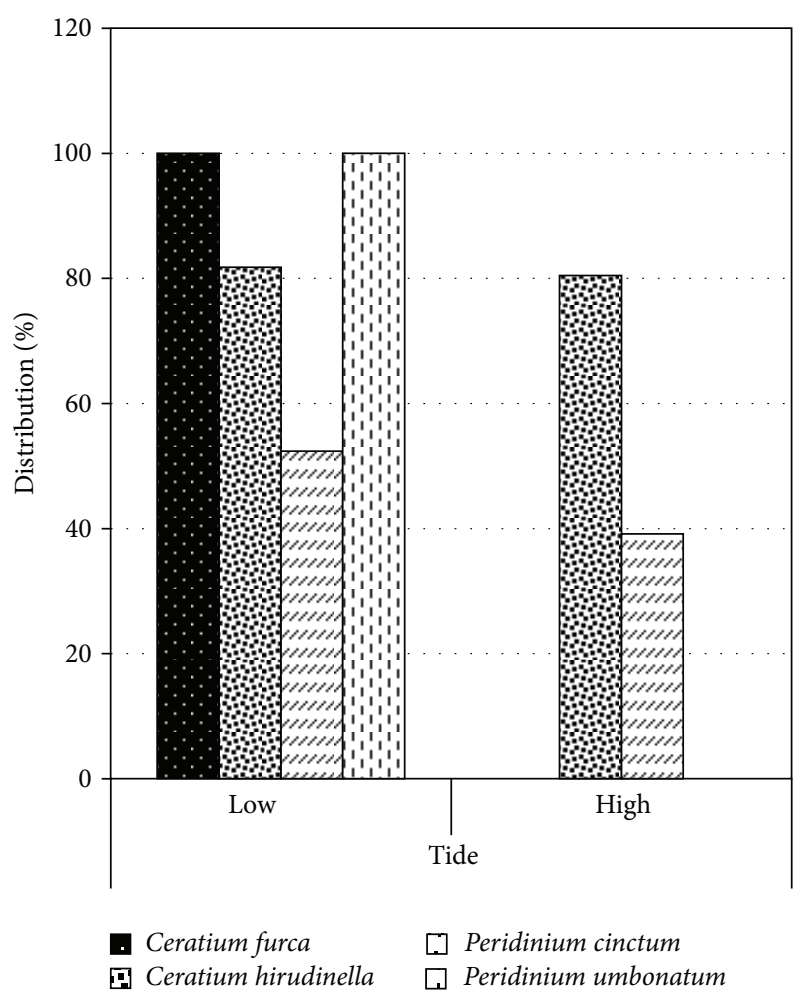

FIgURE 13: Variation of Pyrrophyceae species in relation to tide in Okpoka Creek.

4.8. Xanthophyceae (Xanthophytes). Xanthophytes density ranged significantly between $1097.03 \pm 103.82 \mathrm{no} / \mathrm{mL}$ (low tide) and $2372.64 \pm 243.52 \mathrm{no} / \mathrm{mL}$ (high tide $)(P<0.05$, DMR). The mean diversity indices were significantly high (DMR) at low tide than at high tide as follows: Margalef $0.03 \pm 0.02$ and $0.14 \pm 0.02$, Shannon $0.04 \pm 0.02$ and $0.09 \pm$ 0.01 , Evenness $0.04 \pm 0.03$ and $0.13 \pm 0.02$, and Dominance $0.05 \pm 0.16$ and $0.16 \pm 0.02$. Passive transport process, advection cycle, settling, and resuspension that follow the suspended particles during the ebb, slack, and flood tidal stages could be the possible reasons for this observation. Low tide similarity and dissimilarity indices were $38.68 \pm 5.57 \%$ and $61.32 \pm 5.62 \%$, respectively, while high tide similarity and dissimilarity indices were $13.40 \pm 7.16 \%$ and $86.60 \pm 7.16 \%$, respectively. Tidal influences on these indices were not significant $(P>0.05, \mathrm{DMR})$. This indicated that xanthophytes were not similarly distributed at low tide.

One genus and 2 species of xanthophyceae, namely, Tribonema viride $(53.21 \pm 10.58 \%)$ and T. vulgare $(81.55 \pm$ $6.33 \%$ ) were observed (Figure 14). From Figure 15, high tide distribution percentages were significantly higher than that of low tide percentages of abundance of species $(P<0.05$, DMR). T. viride had distribution percentages of $50.29 \pm$ $11.39 \%$ at low tide and $64.90 \pm 35.11 \%$ at high tide. T. vulgare had distribution percentages of $79.85 \pm 7.37 \%$ at low tide and $90.07 \pm 9.93 \%$ at high tide.

4.9. Chrysophyceae (Chrysophytes). Chrysophytes ranged insignificantly $(P>0.05, \mathrm{DMR})$ from $124.25 \pm 33.99 \mathrm{no} / \mathrm{mL}$

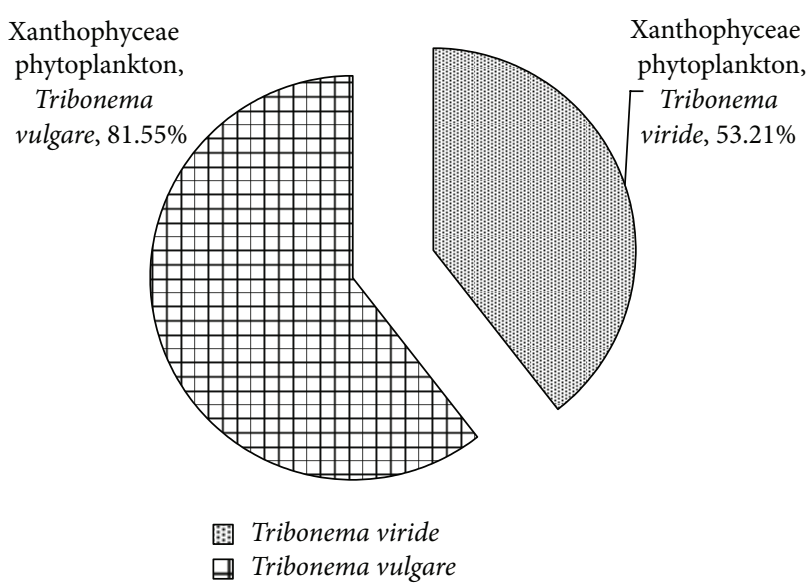

FIGURE 14: Overall mean values of Xanthophyceae species in Okpoka Creek.

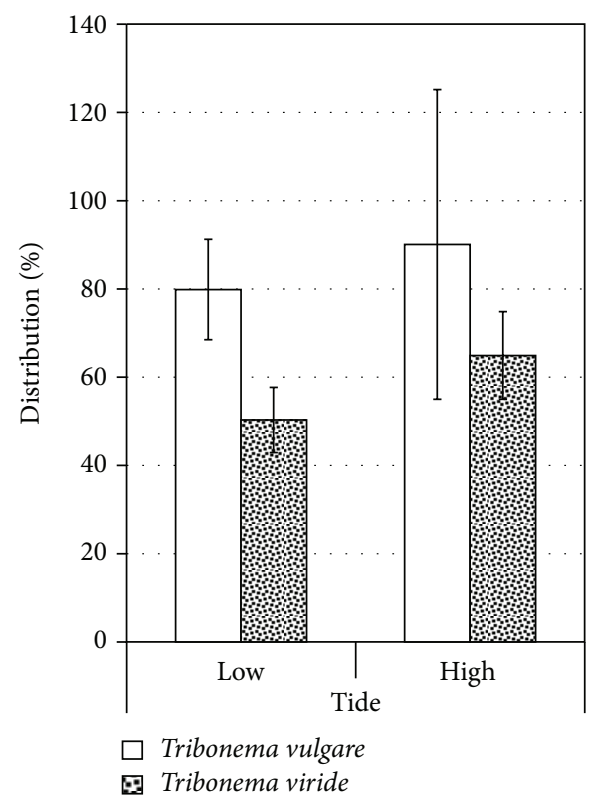

FIGURE 15: Variation of Xanthophyceae species in relation to tide in Okpoka Creek.

(high tide) to $495.31 \pm 79.33 \mathrm{no} / \mathrm{mL}$ (low tide) with a mean of $457.267 \pm 3.46 \mathrm{no} / \mathrm{mL}$ which was $4.01 \%$ total phytoplankton abundance. The possible reasons for this observation are similar to those of xanthophytes. Also, it could indicate the stress condition of Okpoka Creek and that they are not resilient algae. All species diversity indices were zero signifying very low species diversity. Only 1 species, Dinobryon sertularia, was observed. This might mean similarity index $(15.15 \pm 6.34 \%)$ and dissimilarity index $(84.85 \pm 6.34 \%)$ of chrysophytes were recorded. Tide had no significant effects on similarity and dissimilarity indices $(P>0.05$, DMR). Dissimilarity index of species was higher at high tide indicating that chrysophytes were differently distributed at high tide. 


\section{Conclusion}

Tide has varied effects on the nutrients status and phytoplankton community (in terms of species composition, diversity, abundance, and distribution) of Okpoka Creek. Phosphate and ammonia (organic pollutants) exceeded FEPA and USEPA acceptable levels of $0.10 \mathrm{mg} / \mathrm{L}$ and $0.10 \mathrm{mg} / \mathrm{L}$, respectively, for natural water bodies indicating high nutrient status, organic matter, and potential pollutants in this creek. Diatoms are the dominant phytoplankton while euglenoids are the passive (least) phytoplankters. They are sensitive and resilient to both low and high tides. Organic pollution indicator species: Navicula gracilis, N. cuspidata, N. placentula, N. microcephala, N. bacillum, N. amphibola, Nitzschia sigma, $N$. bilobata, N. lanceolata, N. filiforms, N. longissima, Cymbella cuspidata, C. lata, Tabellaria fenestrate, Synedra ulna, Cyclotella meneghiniana, Cocconeis placentula, Pinnularia major (diatoms), Cladophora glomerata, Scenedesmus spp, (green algae), Euglena acus (euglenoid), Anabaena spiroides, Microcystis pulverea (blue-green algae), and Ceratium furca (dinoflagellate) were recorded at either only low, high or both tides. The flushing action of the tidal flows contributes to moving these pollutants down into this creek.

\section{Recommendation}

Tide is a major determinant of tidal variations. This study therefore suggests the high-resolution monitoring programs that are essential to capture the natural variability of phytoplankton in coastal waters. Concerted environmental surveillance on Upper Bonny Estuary is advocated to reduce the inflow of pollutants from the Bonny Estuary into this creek caused by tidal influence. Aquatic scientists should be encouraged to conduct further researches on tidal effects on other aspects of the biology and ecology of phytoplankton in Okpoka Creek and other tributaries of Bonny Estuary as well as the Bonny Estuary at large in order to bridge the gap in knowledge of the abiotic and biotic properties of this estuary.

\section{References}

[1] H. Badsi, H. Oulad Ali, M. Loudiki, and A. Aamiri, "Phytoplankton diversity and community composition along the salinity gradient of the massa estuary," American Journal of Human Ecology, vol. 1, no. 2, pp. 58-64, 2012.

[2] B. H. Wilcox, "Angiosperm flora of the Niger Delta mangal: a taxonomic review," in Proceedings of Workshop on the Niger Delta Mangrove Ecosystem, pp. 19-23, Port Harcourt, Nigeria, October 1980.

[3] F. Villate, "Tidal influence on zonation and occurrence of resident and temporary zooplankton in a shallow system (Estuary of Mundaka, Bay of Biscay)," Scientia Marina, vol. 61, no. 2, pp. 173-188, 1997.

[4] J. M. Trigueros and E. Orive, "Tidally driven distribution of phytoplankton blooms in a shallow, macrotidal estuary," Journal of Plankton Research, vol. 22, no. 5, pp. 969-986, 2000.

[5] C. Riaux-Gobin, "Phytoplankton, tripton et microphytobenthos: échanges au cours de la mareé, dans un estuaire du NordFinistère," Cahiers de Biologie Marine, vol. 28, pp. 159-184, 1987.
[6] L. A. Morales-Zamorano, R. Cajal-Medrano, E. OrellanaCepeda, and L. C. Jimenez-Perez, "Effect of tidal dynamics on a planktonic community in a coastal lagoon of Baja California, Mexico," Marine Ecology Progress Series, vol. 78, no. 3, pp. 229239, 1991.

[7] J. E. Cloern, “Tidal stirring and phytoplankton bloom dynamics in an estuary," Journal of Marine Research, vol. 49, no. 1, pp. 203$221,1991$.

[8] L. V. Lucas and J. E. Cloern, "Effects of tidal shallowing and deepening on phytoplankton production dynamics: a modeling study," Estuaries A, vol. 25, no. 4, pp. 497-507, 2002.

[9] A. N. Blauw, E. Benincà, R. W. P. M. Laane, N. Greenwood, and J. Huisman, "Dancing with the tides: fluctuations of coastal phytoplankton orchestrated by different oscillatory modes of the tidal cycle," PLoS ONE, vol. 7, no. 11, Article ID e49319, 2012.

[10] K. M. Rajesh, G. Gowda, and R. M. Mridula, "Primary productivity of the brackishwater impoundments along Nethravathi estuary, Mangalore in relation to some physico-chemical parameters," Fishery Technology, vol. 39, no. 2, pp. 85-87, 2002.

[11] G. Ananthan, P. Sampathkumar, P. Soundarapandian, and L. Kannan, "Observations on environmental characteristics of Ariyankuppam estuary and Verampattinam coast of Pondicherry," Journal of Aquatic Biology, vol. 19, pp. 67-72, 2004.

[12] A. Tiwari and S. V. S. Chauhan, "Seasonal phytoplanktonic diversity of Kitham lake, Agra," Journal of Environmental Biology, vol. 27, no. 1, pp. 35-38, 2006.

[13] B. Tas and A. Gonulol, "An ecologic and taxonomic study on phytoplankton of a shallow lake, Turkey," Journal of Environmental Biology, vol. 28, no. 2, pp. 439-445, 2007.

[14] A. Saravanakumar, J. Sesh Serebiah, G. A. Thivakaran, and M. Rajkumar, "Benthic macrofaunal assemblage in the arid zone mangroves of gulf of Kachchh-Gujarat," Journal of Ocean University of China, vol. 6, no. 3, pp. 303-309, 2007.

[15] P. Ponmanickam, T. Rajagopal, M. K. Rajan, S. Achiraman, and K. Palanivelu, "Assessment of drinking water quality of Vembakottai reservoir, Virudhunagar district, Tamil Nadu," Journal of Experimental Zoology, vol. 10, no. 2, pp. 485-488, 2007.

[16] T. R. Shashi Shekhar, B. R. Kiran, E. T. Puttaiah, Y. Shivaraj, and K. M. Mahadevan, "Phytoplankton as index of water quality with reference to industrial pollution," Journal of Environmental Biology, vol. 29, no. 2, pp. 233-236, 2008.

[17] American Public Health Association (APHA), Standard Method for the Examination of Water and WasteWater, McGraw-Hill, Washington DC, USA, 16th edition, 1985.

[18] C. E. Boyd, Water Quality in Warmwater Fish Ponds, Craftmaster, Auburn, Alabama, USA, 2nd edition, 1981.

[19] J. G. Needham and P. R. Needham, A Guide to the Study of Freshwater Biology, Holden-Day, San Francisco, Calif, USA, 2nd edition, 1962.

[20] G. E. Newell and R. C. Newell, Marine Plankton: A Practical Guide, Hutchinson Publishing Limited, London, UK, 1st edition, 1963.

[21] R. Patrick and C. Reimer, The Diatoms of the United States Exclusive Alaska and Hawaii T. Fragillariaceae, Eunoticeae, Achnanthaceae, Naviculaceae, Livingstone, Philadelphia, Pa, USA, 1966.

[22] M. Han, Illustration of Freshwater Plankton, Agricultural Press, Auburn, Alabama, USA, 1st edition, 1978.

[23] J. R. Durans and C. Leveque, "Flore et farune aquatiquesde 1, afrique-an-off erch," Science Technica Qutre-Mer, vol. 1, pp. 5$46,1980$. 
[24] G. W. Prescott, How to Know the Freshwater Algae, McGrawHill, Washington, DC, USA, 1982.

[25] M. O. Kadiri, "A taxonomic study of the genus Closterium (Nizch. 1919), Ralfs 1945 (Desmichaceae Chlorophyta) in small Nigeria Reservoir with ecological notes," Tropical Freshwater Biology, vol. 1, pp. 71-90, 1988.

[26] E. P. Odum, Fundamentals of Ecology, W.B. Saunders, London, UK, 3rd edition, 1971.

[27] Statistical Analysis System (SAS), User's Guide SAS/STA-T version, SAS Institute, Cary, NC, USA, 8th edition, 2003.

[28] M. Yamamuro, I. Koike, and H. Iizumi, "Partitioning of the nitrogen stock in the vicinity of a Fijian seagrass bed dominated by Syringodium isoetifolium (Ascherson) Dandy," Australian Journal of Marine \& Freshwater Research, vol. 44, no. 1, pp. 101115, 1993.

[29] R. V. Thurston, R. C. Russo, and G. A. Vinogradov, "Ammonia toxicity to fishes. Effect of $\mathrm{pH}$ on the toxicity of the un-ionized ammonia species," Environmental Science and Technology, vol. 15, no. 7, pp. 837-840, 1981.

[30] R. N. McNeely, V. P. Neimanis, and L. Dwyer, Water Quality Sourcebook: A Guide to Water Quality Parameters, Inland Waters Directorate, Water Quality Branch, Ottawa, Canada, 1979.

[31] Environmental Studies Board (ESB), "Water quality criteria 1972," Committee of Water Quality Criteria Report EPA-R3-73033, Environmental Protection Agency, Washington, DC, USA, 1973.

[32] A. C. Chindah and U. Nduaguibe, "Effect of tank farm wastewater on water quality and periphyton of Lower Bonny River Niger Delta, Nigeria," Journal of Nigeria Environmental Society, vol. 1, no. 2, pp. 206-222, 2003.

[33] C. C. Obunwo, S. A. Braide, W. A. L. Izonfuo, and A. C. Chindah, "Influence of urban activities on the water quality of a fresh water stream in the Niger Delta, Nigeria," Journal of Nigerian Environmental Society, vol. 2, no. 2, pp. 196-209, 2004.

[34] L. Zimmerman, "Phytoplankton-national estuarine research reserve," 2013, http://nerrs.noaa.gov/doc/siteprofile/acebasin/ html/biores/phy.

[35] T. A. Frankovich, E. E. Gaiser, J. C. Zieman, and A. H. Wachnicka, "Spatial and temporal distributions of epiphytic diatoms growing on Thalassia testudinum Banks ex König: relationships to water quality," Hydrobiologia, vol. 569, no. 1, pp. 259-271, 2006.

[36] J. Creswell, R. Karasack, R. Johnson, and H. Shayler, "Nitrogen and phosphorus in limitation in Mill and Green ponds and the effects of nutrient enrichment," Macalester Environmental Review, 2001.

[37] P. M. Vitousek and R. W. Howarth, "Nitrogen limitation on land and in the sea: how can it occur?" Biogeochemistry, vol. 13, no. 2, pp. 87-115, 1991.

[38] European Economic Community (EEC), "Council directive on the quality of freshwater needing protection or improvement in order to support fish life," Offshore Journal of European Commununities, L259, pp. 1-10, 1979.

[39] United States Environmental Protection Agency (USEPA), "Nitrate-Water," 2000, http://water.epa.gov/type/rsl/monitoring/vms57.cfm.

[40] United States Geological Survey (USGS), "Nutrients in the Nation's Waters-Too Much of a Good Thing?" 2013, http:// pubs.usgs.gov/circ/circl136/circ1136.html.
[41] N. Ebere, The impact of oil refinery effluents on the distribution, abundance and community structure of macro-benthos in Okrika Creek [Ph.D. thesis], Department of Biological Sciences, Rivers state University of Science and Technology, 2002.

[42] A. J. Edoghotu, The ecological quotients (EQ) of point source of pollution along Okpoka Creek, Port Harcourt [M.S. thesis], Department of Biological Sciences, Rivers State University of Science and Technology, 1998.

[43] A. C. Chindah and R. I. Keremah, "Physico-chemistry and phytoplankton of a brackish water fish pond of the Bonny Estuary Nigeria," African Journal of Environmental Studies, vol. 2, no. 2, pp. 63-67, 2001.

[44] A. C. Chindah and S. A. Braide, "Crude oil spill and the phytoplankton community of a swamp forest stream," African Journal of Environmental Studies, vol. 2, no. 1, pp. 1-8, 2001.

[45] A. C. Chindah and S. A. Braide, "The physico-chemical quality and phytoplankton community of tropical waters: a case of 4 Biotopes in the Lower Bonny River, Niger Delta, Nigeria," Caderno de Pesquisa, vol. 16, no. 2, pp. 7-35, 2004.

[46] K. A. Moser, G. M. MacDonald, and J. P. Smol, "Applications of freshwater diatoms to geographical research," Progress in Physical Geography, vol. 20, no. 1, pp. 21-52, 1996.

[47] U. Krumme and T. H. Liang, "Tidal-induced changes in a copepod-dominated zooplankton community in a macrotidal mangrove channel in northern Brazil," Zoological Studies, vol. 43, no. 2, pp. 404-414, 2004.

[48] D. L. Roelke, R. M. Errera, R. Riesling et al., "Effects of nutrient enrichment on Prymnesium parvum population dynamics and toxicity: results from field experiments, Lake Possum Kingdom, USA," Aquatic Microbial Ecology, vol. 46, no. 2, pp. 125-140, 2007.

[49] S. I. Passy, R. W. Bode, D. M. Carlson, and M. A. Novak, "Comparative environmental assessment in the studies of benthic diatom, macroinvertebrate, and fish communities," International Review of Hydrobiology, vol. 89, no. 2, pp. 121-138, 2004.

[50] D. U. Okpuruka, "Tidal and semi-lunar variations in the surface phytoplankton of a Port Harcourt mangrove creek," in Proceedings of the Workshop on Nigerian Wetlands, T. V. I. Akpata and D. U. U. Okali, Eds., pp. 1-183, Lagos, Nigeria, August 1986.

[51] D. I. Nwankwo and A. Akinsoji, "Periphyton algae of a eutrophic Creek and their possible use as indicator," Nigerian Journal of Botany, vol. 1, pp. 47-54, 1988.

[52] D. I. Nwankwo and A. O. Onitiri, "Periphyton community on submerged aquatic macrophytes (Hornwort and Bladderwort) in Epe Lagoon, Nigeria," Journal of Agricultural Science Technology, vol. 2, no. 2, pp. 135-141, 1992.

[53] D. I. Nwankwo and S. A. Amuda, "Periphytic diatoms on three floating aquatic macrophytes in a polluted south-west Nigerian creek," International Journal of Ecology \& Environmental Sciences, vol. 19, no. 1, pp. 1-10, 1993.

[54] D. I. Nwankwo, "Hydrochemical properties and bottom-dwelling diatoms of a Lagos lagoon sewage disposal site," Polskie Archiwum Hydrobiologii, vol. 41, no. 1, pp. 35-47, 1994.

[55] D. I. Nwankwo and K. A. Kasumu-Iginla, "Contributions to the diatom flora of Nigeria 11 Tube-dwelling pinnate diatoms from Lagos Moles," Nigeria Journal of Botany, vol. 10, pp. 61-69, 1997.

[56] D. I. Nwankwo, "Seasonal changes in phytoplankton composition and diversity in the Epe lagoon, Nigeria," Acta Hydrobiology, vol. 40, no. 2, pp. 83-92, 1998. 

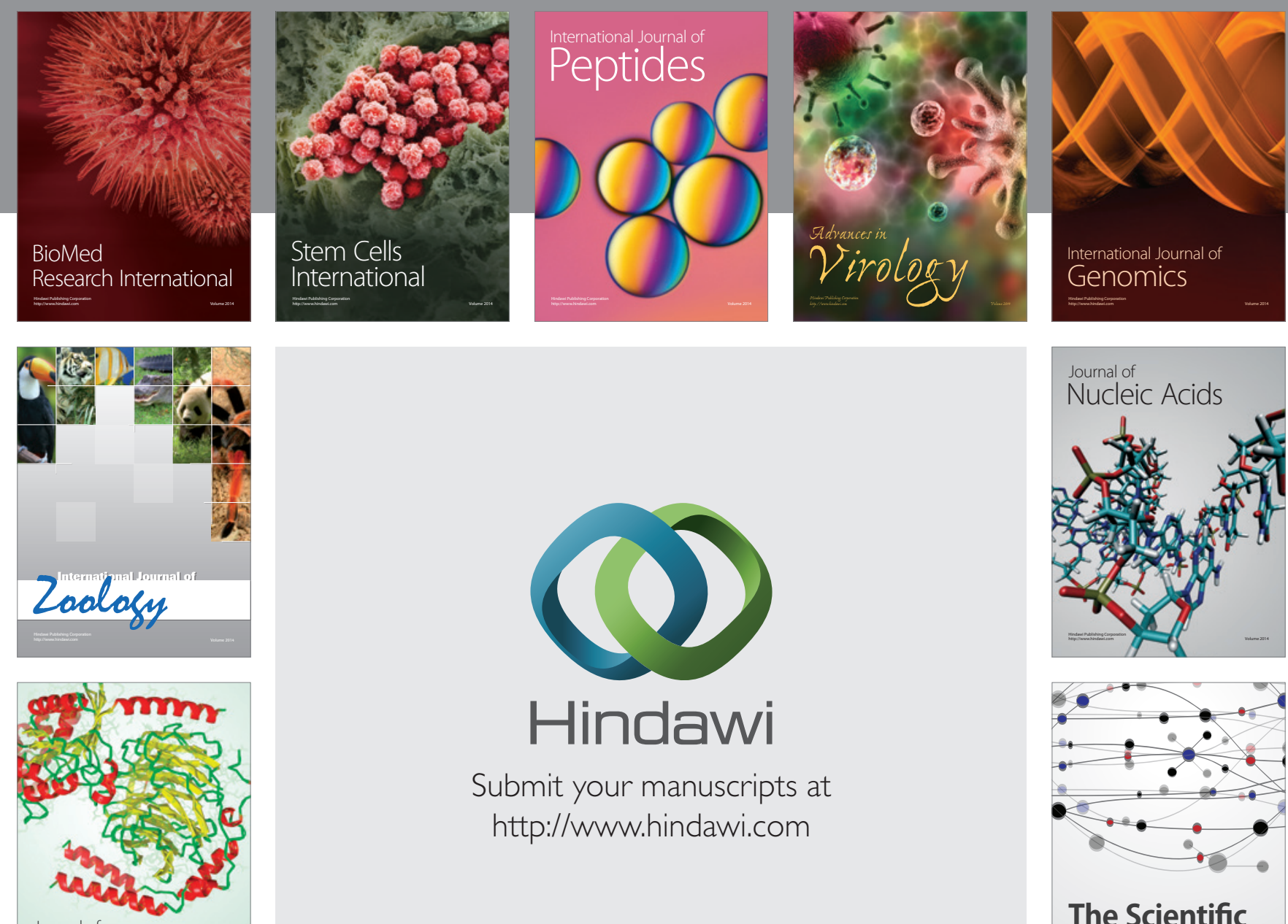

Submit your manuscripts at

http://www.hindawi.com

Journal of
Signal Transduction
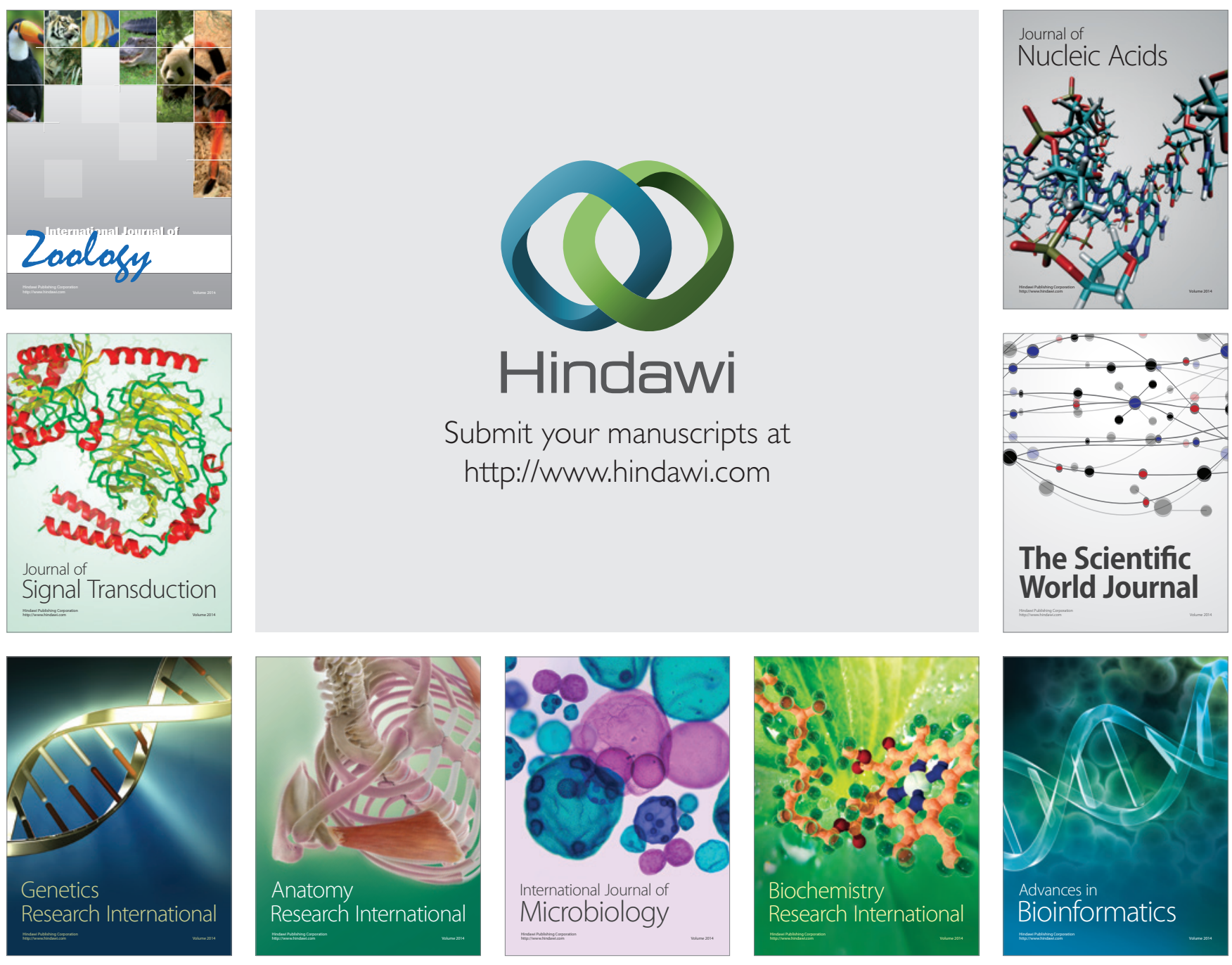

The Scientific World Journal
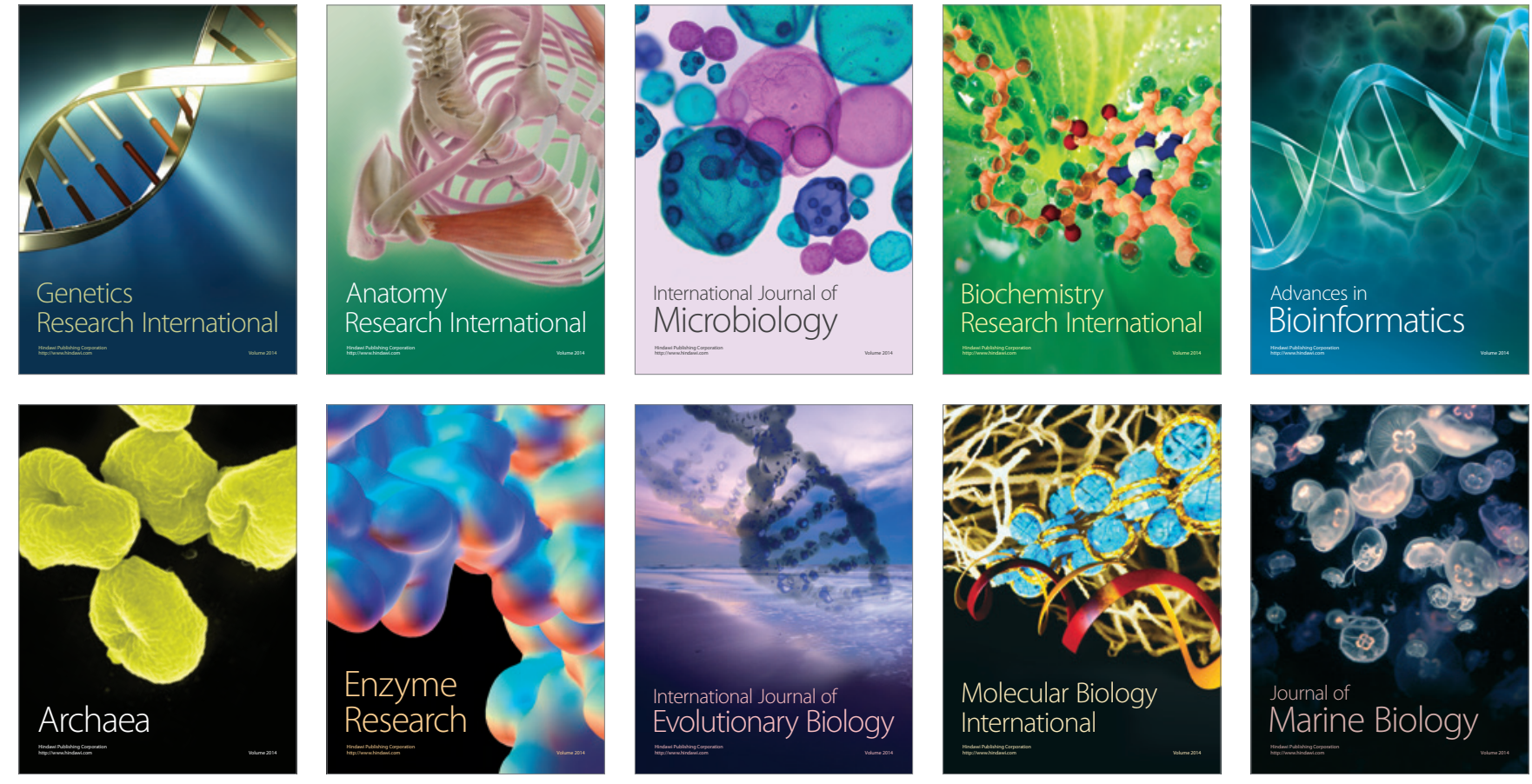